\title{
Selective biologics for ulcerative colitis and Crohn's disease - clinical utility of vedolizumab
}

\author{
This article was published in the following Dove Press journal: \\ Biologics:Targets and Therapy \\ 9 March 2016 \\ Number of times this article has been viewed
}

\section{Jill MV Petkau \\ Bertus Eksteen \\ Snyder Institute for Chronic Diseases, Cumming School of Medicine, University of Calgary, Calgary, $A B$, Canada}

Correspondence: Bertus Eksteen Snyder Institute for Chronic Diseases, Cumming School of Medicine, University of Calgary, 4AC66-3280 Hospital Drive NW, Calgary, AB T2N 4NI, Canada

Tel +l 4032203719

Fax +l 4032109146

Email b.eksteen@ucalgary.ca

\begin{abstract}
Inflammatory bowel disease (IBD) encompasses a cluster of different disease phenotypes which are broadly classified into ulcerative colitis and Crohn's disease. Disease pathogenesis is driven by abnormal host immune responses to their resident gut microbiome in genetically susceptible individuals. Clinical disease features and outcomes are heterogenous and not unexpected as over 163 genetic loci are associated with disease susceptibility, and there are great variability in environmental exposures. Despite this variability, there has been relatively few efficacious therapies for particularly moderate-to-severe IBD. Treatment has been dominated by antitumor necrosis alpha agents with significant success but equally potentially serious adverse events. Therapeutic targeting of leucocyte trafficking has emerged as a viable alternative therapy, with vedolizumab being the lead compound. This review focuses primarily on its biological function as a selective gut immunotherapy, its safety and efficacy, and its emerging role as a mainstream therapy in managing IBD.
\end{abstract}

Keywords: adhesion molecule antagonist, anti- $\alpha 4 \beta 7$ integrin, inflammatory bowel disease, leukocyte trafficking, monoclonal antibody, selective gut immunotherapy, tumor necrosis factor alpha

\section{Introduction}

Crohn's disease (CD) and ulcerative colitis (UC), collectively referred to as inflammatory bowel disease (IBD), are chronic inflammatory conditions of the gastrointestinal (GI) tract resulting from an inappropriate immunological response to trigger(s) in the genetically susceptible host's environment and microbiome. The inflammation of CD is transmural and discontinuous, affecting any portion of the digestive tract, whereas UC is characterized by superficial colonic inflammation that progresses in a continuous manner proximally from the rectum. Diarrhea, blood in the stool, abdominal cramping and pain, fatigue, weight loss, and malnutrition are hallmark symptoms of IBD, often associated with extra-intestinal manifestations involving the joints, skin, eyes, and liver.

IBD affects more than 233,000 Canadians (equating to one in 150 Canadians), with more than 10,000 new cases diagnosed each year, ${ }^{1}$ it is as common as type 1 diabetes and epilepsy, and twice as common as multiple sclerosis and Parkinson's disease. ${ }^{2}$ The incidence and prevalence rates of CD and UC in Canada are reported to be among the highest in the world, ${ }^{1,3}$ and the rate of pediatric-onset IBD diagnoses continues to significantly increase. ${ }^{1}$ Canadian statistics align with global trends of increasing incidence and prevalence of IBD in developed and developing countries. ${ }^{3}$ IBD affects approximately 1.7 million Americans (estimated 780,000 with CD; estimated 907,000 with UC), with an incidence rate of 10.7 per 100,000 persons for CD and 12.2 per 100,000 persons 
with UC. ${ }^{4,5}$ The annual incidence of CD and UC in Europe was reported as 12.7 per 100,000 person-years and 24.3 per 100,000 person-years, respectively, with a reported CD prevalence of 322 per 100,000 persons and UC prevalence of 505 per 100,000 persons. $^{3}$ The incidence and prevalence rates of both $\mathrm{CD}$ and UC in Asia reflect a rising trend, correlating with an increase in industrialization in this area of the world that historically has not experienced significant IBD. ${ }^{3}$ The financial burden of IBD is substantial, with direct medical costs in excess of CAD $\$ 1.2$ billion and indirect costs approximating CAD $\$ 1.6$ billion in $2012 .{ }^{6}$ Health-related quality of life scores are reproducibly decreased in patients living with IBD compared with individuals without IBD. ${ }^{1,7-9}$

Given the significant global burden of IBD, there exists a need for safe and potent biological therapy options to effective treat individuals with moderate-to-severe phenotypes of UC and CD. There has been much speculation as to the potential role of vedolizumab (VDZ) for the treatment of UC and CD when the drug was still development. ${ }^{10,11}$ This review is intended to persuasively demonstrate that VDZ, an anti- $\alpha 4 \beta 7$ integrin antagonist, is an efficacious and safe alternative to tumor necrosis factor alpha (TNF $\alpha)$ antagonist treatment options for both UC and CD without the serious complication of progressive multifocal leukoencephalopathy (PML) previously associated with natalizumab.

\section{Current IBD therapy paradigm}

The goal of medical treatment in IBD is primarily focused on interrupting or modifying the aberrant immune response to induce and sustain mucosal remission so as to 1) minimize complications leading to hospitalizations and surgery; 2) modify extra-intestinal disease; and most importantly, 3) optimize quality of life. ${ }^{12,13}$

\section{Mild-to-moderate UC and Crohn's disease}

Mild-to-moderate disease is most often satisfactorily managed with oral and/or rectal therapies, such as 5-aminosalicylic acid preparations, to induce and maintain remission. Induction of remission can also be achieved with pulsed corticosteroids (CSs), such as oral prednisone or budesonide, which are tapered over a number of weeks. Immunomodulators, such as thiopurines or methotrexate, may be required for remission maintenance in certain individuals. ${ }^{12}$

\section{Moderate-to-severe UC and Crohn's disease}

More severe disease phenotypes will often require frequent courses of CSs (steroid-dependent) or may fail to respond appropriately to steroid therapy (steroid refractory), requiring an escalation to biological therapies (with or without immunomodulators) or progression to surgery. ${ }^{12,13}$ Although there has been an observed global decrease in the surgical rate for individuals with IBD that may be attributed to increased utilization of immunosuppressant and biologic therapies, and access to specialized IBD care, ${ }^{6,14,15}$ surgery will still be required for approximately $23 \%-45 \%$ of individuals with $\mathrm{UC}$ and up to $75 \%$ of individuals with $\mathrm{CD}{ }^{16}$

\section{Biological therapies}

\section{Tumor necrosis factor alpha inhibition}

The dysregulated immune response of IBD triggers activation of the innate immune system which in turn produces cytokines such as TNF $\alpha$, and activation of the adaptive immune system with subsequent recruitment of pro-inflammatory T-cells and B-cells to the colon or small bowel. This consequently leads to a further amplification of pro-inflammatory cytokine release that bind to cognate receptors and activate intercellular pathways, such as JAK and STAT, to mediate tissue inflammation. Biological therapy directed toward the inhibition of anti-TNF $\alpha$ has been studied as a treatment modality for IBD since the early $1990 \mathrm{~s}^{17}$ with the introduction of infliximab (Remicade ${ }^{\circledR}$; Janssen Pharmaceutical, Beerse, Belgium). ${ }^{18}$ Since then, adalimumab (Humira ${ }^{\circledR}$; AbbVie Corporation, North Chicago, IL, USA), ${ }^{19}$ golimumab (Simponi ${ }^{\circledR}$; Janssen Pharmaceutical), ${ }^{20}$ and certolizumab pegol (Cimzia; UCB Inc.; Brussels, Belgium $)^{21}$ have been approved for use in UC and/or CD treatment. These immunoglobulin G1 (IgG1) monoclonal antibodies (mAbs) or Fragment AB, F(ab') ${ }_{2}$ bind to and neutralize soluble and transmembrane $\mathrm{TNF} \alpha$, thereby impeding TNF $\alpha$-receptor binding, disrupting the TNF $\alpha$ inflammatory pathway, and modifying the cellular immune response.

In $\mathrm{CD}$, infliximab (ACCENT 1;22 $\mathrm{SONIC}^{23}$ ) and adali-

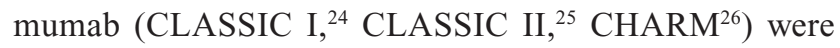
shown to be efficacious in inducing and maintaining sustained clinical response and clinical remission in moderately-toseverely active disease in adults who have not achieved an adequate response with conventional therapy, as well as pediatric patients (infliximab-REACH; ${ }^{27}$ adalimumab-Study M06-806 IMAgINE ${ }^{28}$ ). Additionally, infliximab demonstrated effectiveness in inducing mucosal healing and reducing corticosteroid use (ACCENT 1;22 $\mathrm{SONIC}^{23}$ ), and was shown to be a successful maintenance therapy for fistulizing $C D$ (ACCENT $2^{29}$ ) in this adult population. Table 1 summarizes the pivotal anti-TNF $\alpha$ studies conducted in CD.

Similarly, in UC, efficacious induction and sustained maintenance of clinical response and clinical remission in adults with moderately-to-severely active disease can be achieved 


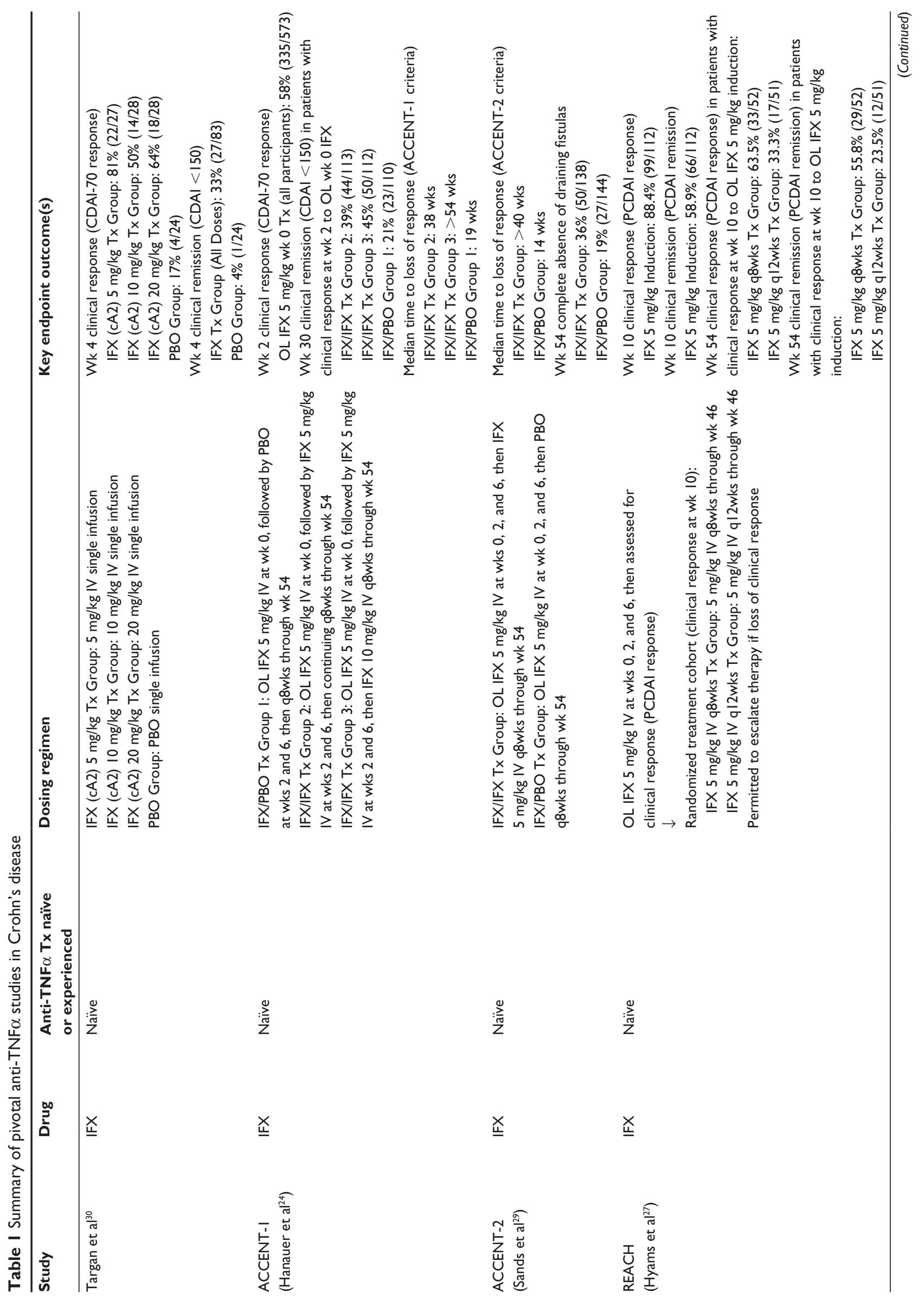




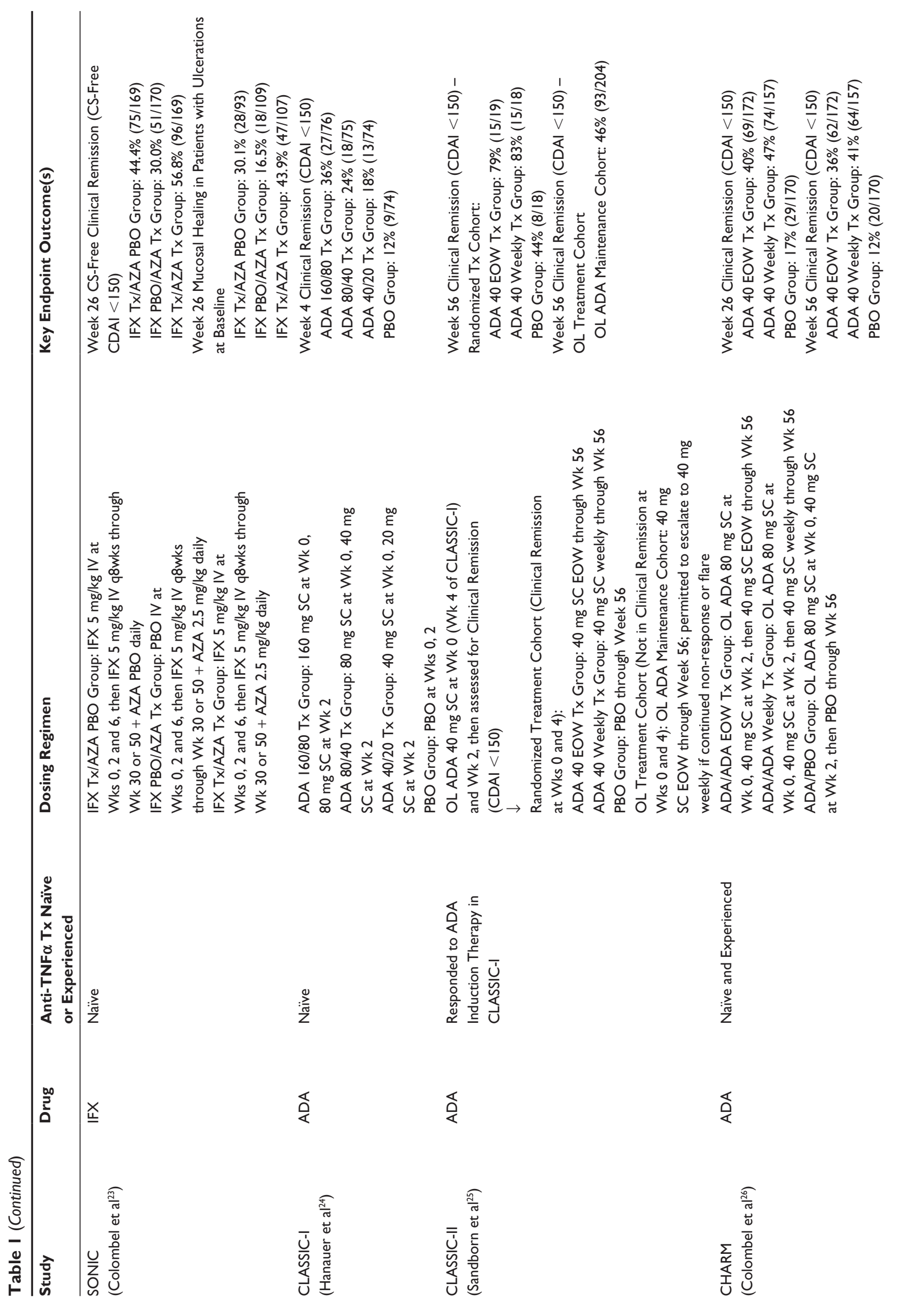



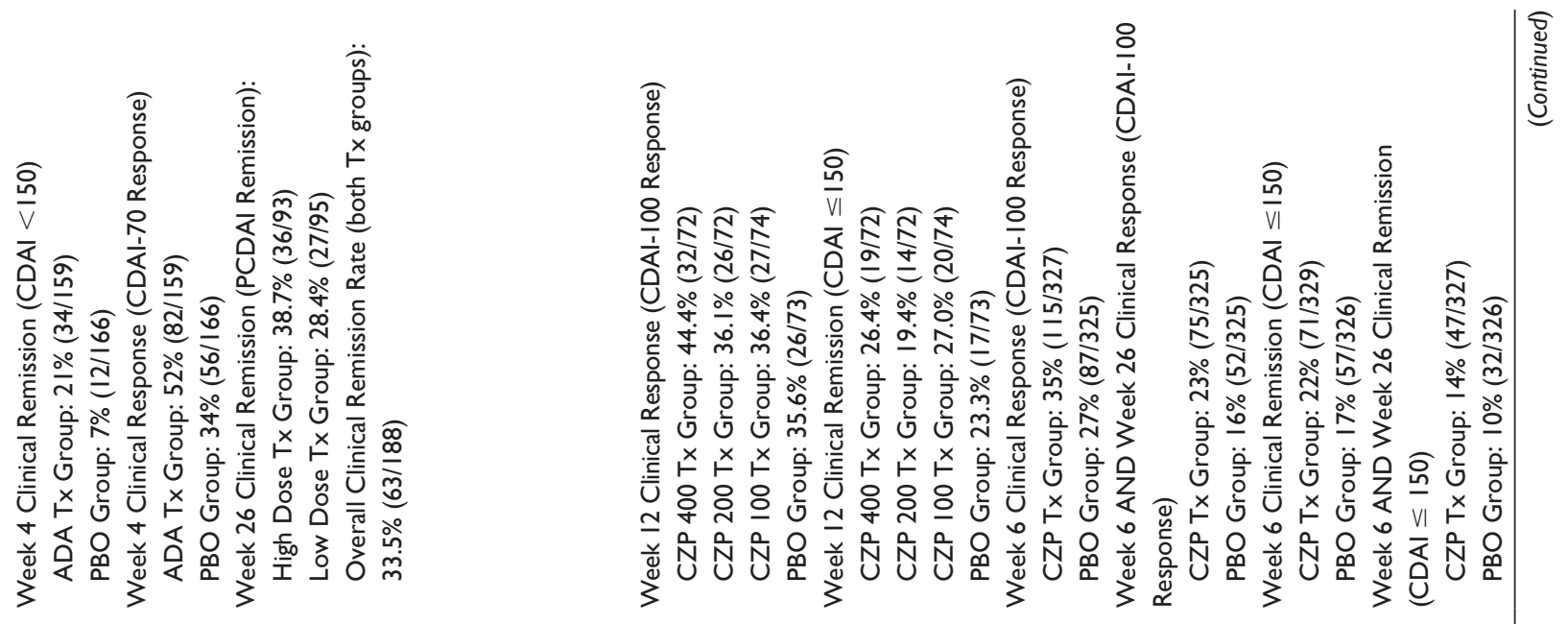

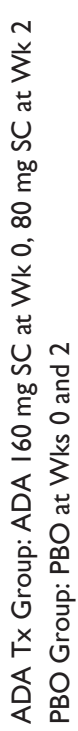
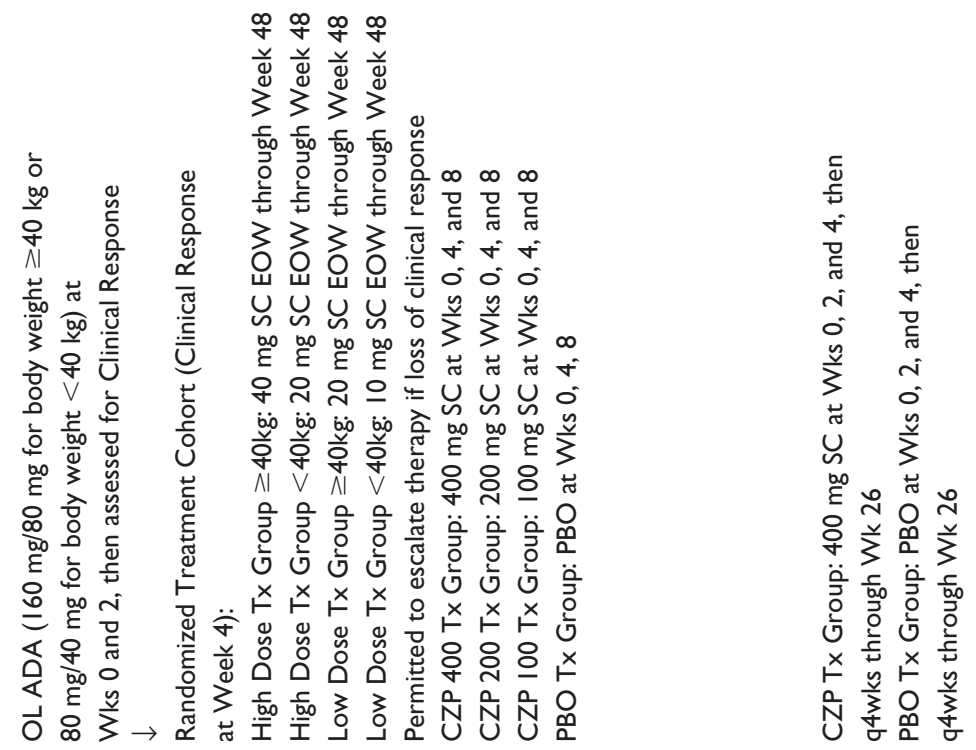

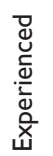

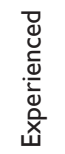

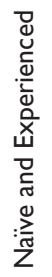

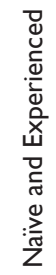

选 荌

กิ

กิ

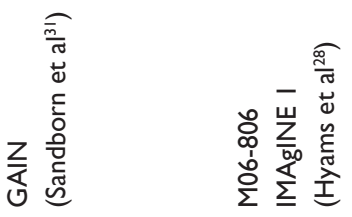

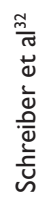

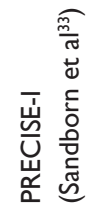




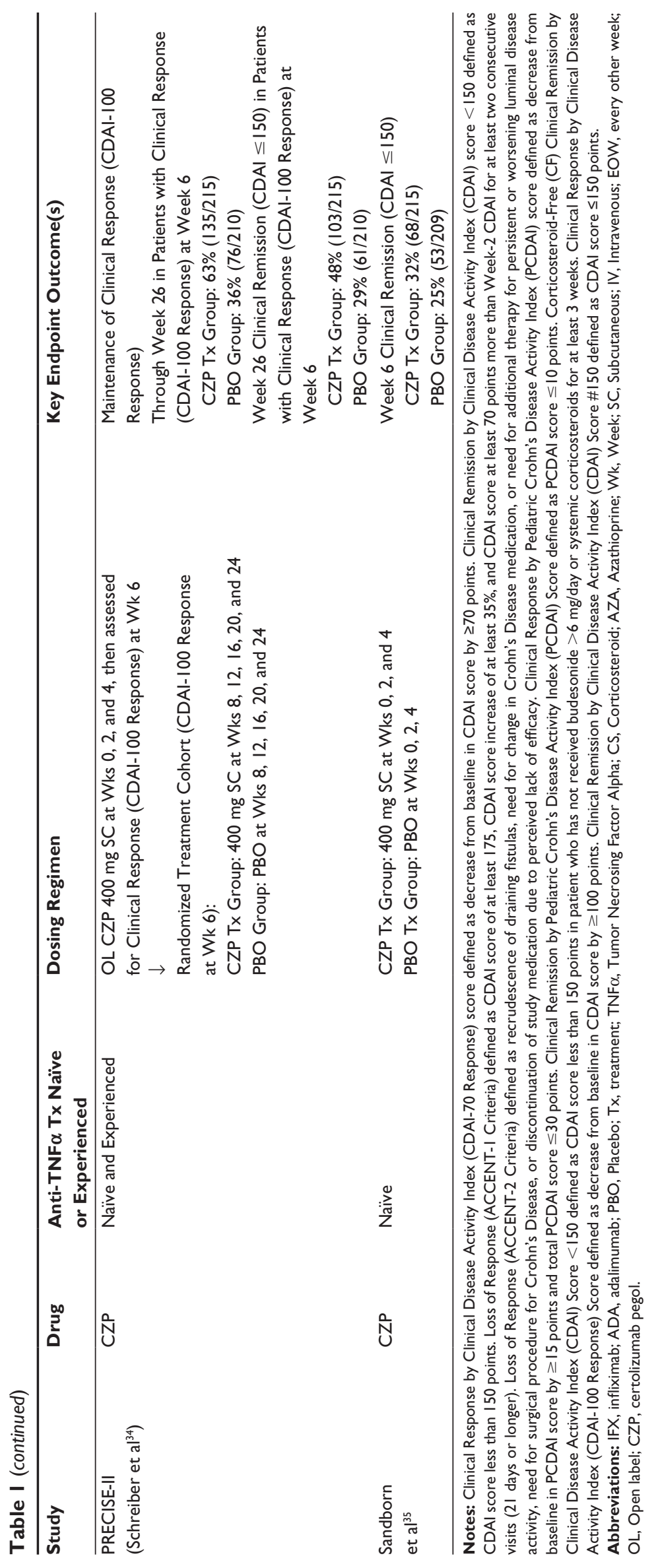


with infliximab (ACT 1 and ACT $2^{36}$ ) and adalimumab (ULTRA $1 ;{ }^{37}$ ULTRA $2^{38}$ ), and less robustly with golimumab (PURSUIT-SC; ${ }^{39}$ PURSUIT-M ${ }^{40}$ ). Infliximab was also shown to be effective in inducing mucosal healing and reducing corticosteroid use (ACT 1 and ACT $2^{36}$ ). Infliximab is the only TNF $\alpha$ inhibitor to be approved for pediatric patients with moderately-to-severely active UC, due to its effectiveness in inducing and maintaining sustained clinical response, clinical remission, and mucosal healing (Study Peds UC ${ }^{41}$ ). Table 2 summarizes the pivotal anti-TNF $\alpha$ studies conducted in UC.

\section{Complications of TNF $\alpha$ inhibitors}

\section{Safety profile and adverse events}

Due to the nonselective and total body mechanism of action of TNF $\alpha$ inhibitors, they are associated with important safety issues. Medically significant adverse events that have been reported for the TNF $\alpha$-blocking drug class in clinical trials, post-marketing registries, and pharmacovigilance systems include: serious infections (bacterial, mycobacterial, viral, parasitic, invasive fungal, and other opportunistic infections), tuberculosis (new infection or reactivation of latent infection), lymphoma (including hepatosplenic T-cell lymphoma) and other malignancies, pediatric malignancies, new or worsening congestive heart failure, hematologic abnormalities and blood dyscrasias, hepatobiliary events, hepatitis B virus reactivation, hypersensitivity reactions (including allergic reactions, anaphylactic reactions, acute infusion reactions, and serum sickness-like reactions), autoimmunity (including autoantibodies and lupus-like syndrome), and central nervous system and peripheral demyelinating disorders. ${ }^{18-21}$ Live vaccine administration is not recommended in patients receiving TNF $\alpha$ inhibitors because of the risk of clinical and disseminated infections. ${ }^{18-21}$

\section{Primary and secondary loss of response}

Despite the high effectiveness of anti-TNF $\alpha$ therapies in patients with IBD, more than one-third of patients are primary nonresponders, and another one-third develop secondary loss of response. Optimal clinical response requires the maintenance of clinically effective drug concentrations which is highly variable among IBD patients and can be influenced by numerous factors such as sex, body weight, associated treatments (immunomodulatory drugs are known to increase anti-TNF $\alpha$ trough levels), route of administration, serum albumin concentration, and systemic inflammation with a markedly decreased half-life in patients with severe disease. ${ }^{43}$ However, the main factor that impacts anti-TNF $\alpha$ pharmacokinetics and efficacy over time is immunogenicity, whereby anti-drug antibodies accelerate anti-TNF $\alpha$ mAb clearance and shorten the drug's half-life. ${ }^{43}$ Although humanized (ie, certolizumab) and fully human mAbs (ie, adalimumab and golimumab) are logically less immunogenic when compared with chimeric ones (ie, infliximab), they can all induce anti-drug antibodies that target the murine and/or variable domains of the drug molecule. Other factors may promote immunogenicity such as genotype in a minority of patients, and drug agitation or freeze-thaw cycles that can induce immunogenic protein aggregates. Concomitant immunomodulator use has been shown to reduce the risk of anti drug antibodies. ${ }^{44}$

\section{Targeting of leukocyte trafficking in IBD}

Until recently, targeting the pro-inflammatory cytokines TNF $\alpha$ and $1 \mathrm{~L}-12 / 23$ (Ustekinumab) ${ }^{45,46}$ have been the only treatments for individuals with moderately-to-severely active $\mathrm{CD}$ or $\mathrm{UC}$ (unresponsive or inadequately responsive to $\mathrm{CS}$ and immunomodulators), yet a significant proportion of such patients will be refractory to these biological drug classes or eventually lose response to therapy. This has resulted in intense investigations to identify other cytokines and pathways that become activated in the dysregulated immune response of IBD. The most advanced alternative to TNF $\alpha$ antagonists has been therapy that targets integrins which mediate trafficking of lymphocytes to the gut. In order to understand how these novel inhibitors of lymphocyte recruitment function, it is crucial to have a basic overview of the molecules involved in gut-specific immune cell recruitment. ${ }^{47}$

\section{Biological basis of leukocyte trafficking in IBD}

Dendritic cells (DCs), strategically positioned in the lamina propria in close proximity to small bowel enterocytes, continuously monitor the luminal microenvironment for antigens. When a potential antigen is encountered, these $\mathrm{CD} 103+\mathrm{DCs}^{48}$ preferentially migrate to secondary lymphoid tissues, such as mesenteric lymph nodes and Peyer's patches, and interact with naïve T- and B-cells to imprint knowledge of the gutderived antigen. ${ }^{49}$ The appropriate immune response, either pro-inflammatory (for a potentially harmful antigen) or tolerance (for an auto-antigen), is thereby generated. Additionally, this interaction induces gut specificity, an important feature of regional immunity, as these newly programmed lymphocytes will be directed back to the gut where they are most likely to encounter the antigen..$^{50}$ Figure 1 demonstrates the key interactions between DCs and naïve T-cells. 


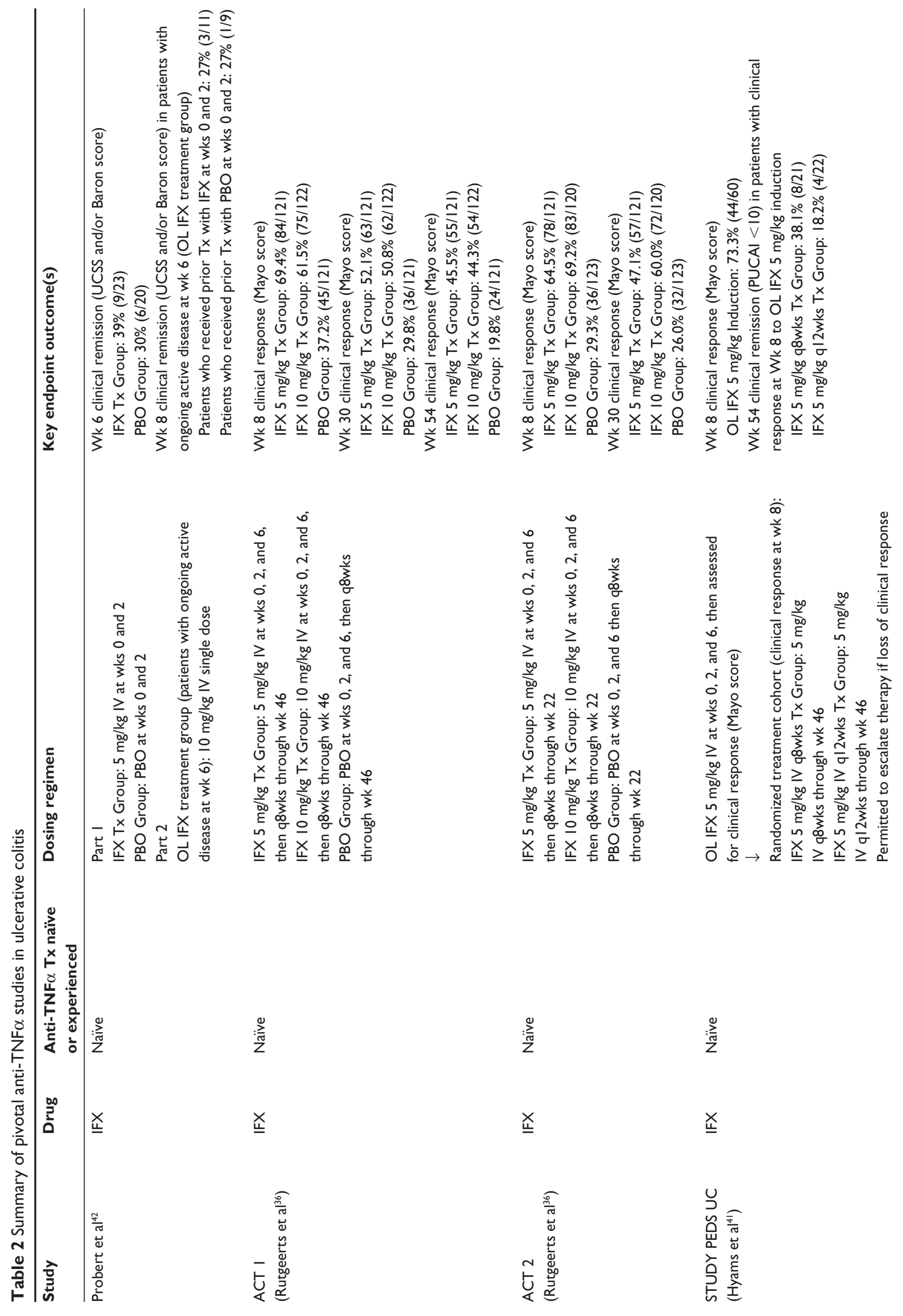




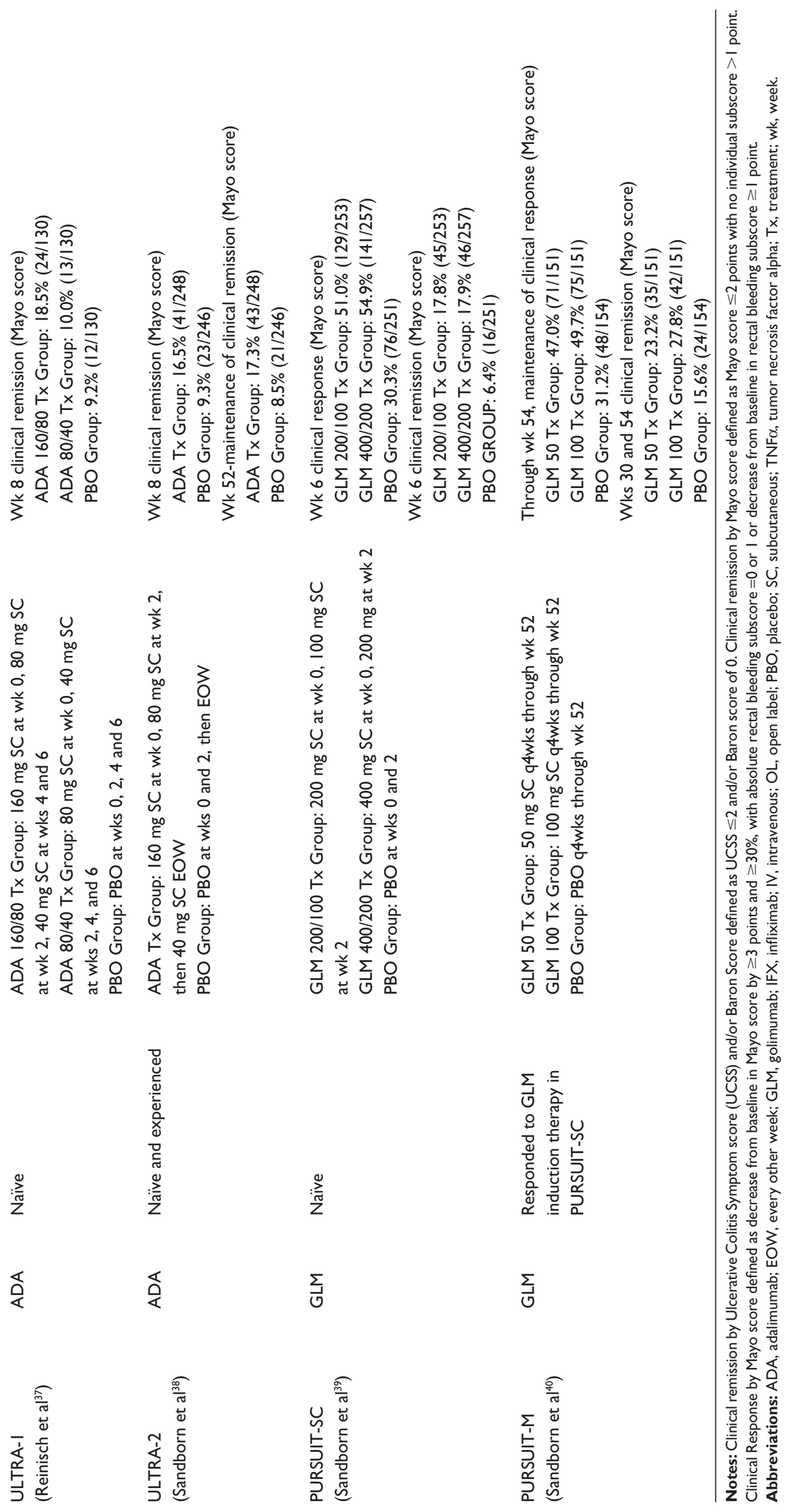


Gut-derived DCs that express CD103 (integrin alpha-E) ${ }^{48}$ have the capacity to convert retinol to all-trans retinoic acid, driving the process of gut specificity. The production of all-trans retinoic acid during lymphocyte priming induces the expression of the chemokine receptor CCR9 and the integrin combination of $\alpha 4 \beta 7$ on the surface of T- and B-lymphocytes, providing a molecular gut-specific postal code. ${ }^{51,52}$ Once these newly generated effector T-cells and IgA-producing B-cells exit the mesenteric lymphoid tissues, they enter the systemic circulatory system and are selectively recruited to gut. Circulating T- and B-lymphocytes interact with selectins ( $\mathrm{P}$ - and E-selectins) expressed on the surface of endothelial cells that line the small venule beds within the intestinal tract. This tethering process slows down the velocity of the lymphocytes and allows them to roll along the endothelium to sample the microenvironment for potential chemokines that could trigger recruitment. CCL25, a chemokine whose expression is restricted to the gut, binds with CCR9 on the surface of the gut-homing lymphocytes, thereby activating the integrin $\alpha 4 \beta 7$ to bind with MAdCAM-1. These tight adhesions cause arrest of the lymphocyte on the endothelium with subsequent migration and extravasation into target tissue. ${ }^{53}$ Figure 2 summarizes these key molecules and drugs currently under development to target them in IBD.

Although CCR9, $\alpha 4 \beta 7$, CCL25, and MAdCAM-1 represent the major elements of gut specificity, other integrins and chemokines are also expressed in the gut during inflammation, including $\alpha 4 \beta 1$ which binds to VCAM-1 and the CXCR3 ligands, CXCR9, and CXCR10. These molecules do not contribute to tissue specificity, but rather are a feature of generalized inflammation that can be found at other sites in the body. ${ }^{50}$

\section{Pre clinical targeting of leukocyte trafficking in IBD}

In IBD, inflammation and resulting tissue injury depends on the recruitment of inflammatory cells - leukocytes such as neutrophils, lymphocytes, and monocytes - to the involved intestinal mucosa from the vascular system, in response to signaling mechanisms and mediators. ${ }^{54}$ The result is sustained inflammation and ongoing tissue damage. Early pre-clinical experiments focused on interfering with lymphocyte homing to the gut by targeting $\alpha 4$ integrins. Using cotton-top tamarins (CTTs) as an ideal study model of colitis given the symptomatic, histologic, and treatment response similarities to UC in humans, Podolsky et $\mathrm{al}^{55}$ reported a statistically significant reduction in acute colonic inflammation in histological samples following the administration of anti- $\alpha 4$ integrin $\mathrm{mAb}$. This disrupted adhesion mediated by both $\alpha 4 \beta 1$ and $\alpha 4 \beta 7$ integrins on the surface of gut-homing leukocytes. In this placebo-controlled blinded trial, HP1/2 mAb $2 \mathrm{mg} / \mathrm{kg}$ $(n=12$ CTT) or placebo $(n=12$ CTT) was administered intramuscularly on days $0-7$, with blinded evaluation of acute colonic activity of day 0 and day 10 colonic mucosal pinch biopsies. The mean histologic activity grade, used to quantify colonic inflammation, was significantly reduced with the HP1/2 treatment group when comparing pre-treatment and post-treatment scores $(1.6 \pm 0.3$ pre-treatment vs $0.2 \pm 0.1$ posttreatment; $P=0.005$ ), and when the HP1/2 treatment group was compared with placebo control group for mean $\Delta$ in pre-treatment/post-treatment scores for each arm (1.4 vs 0.6;

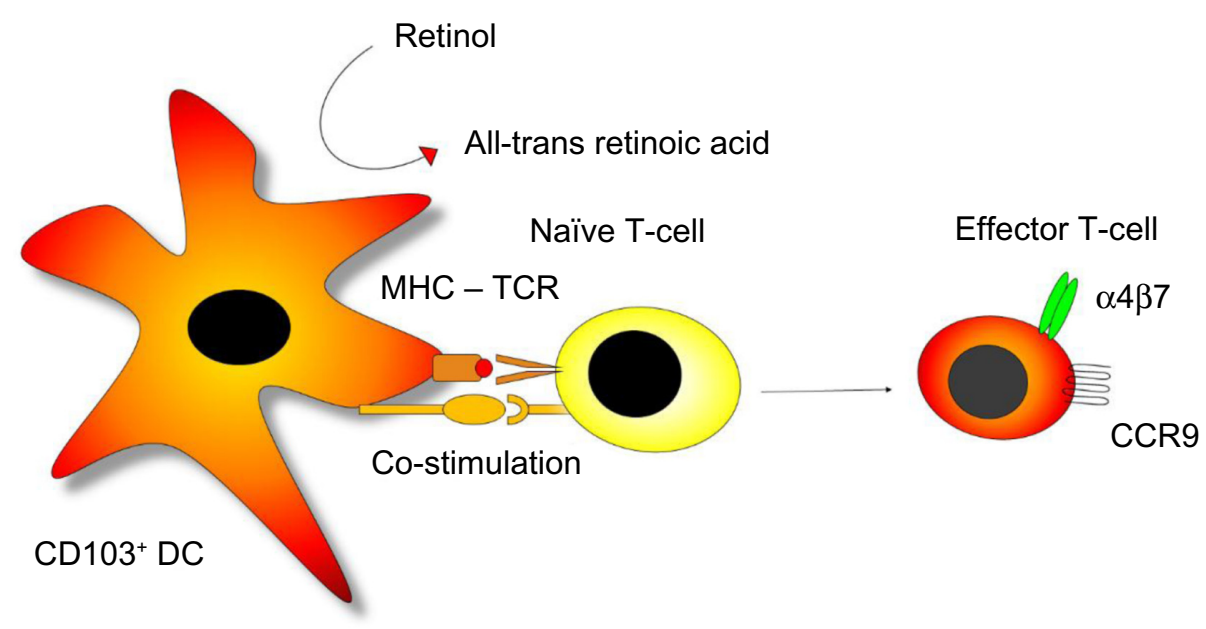

Figure I CDI03+ expressing dendritic cells (CDI03+ DC) present an antigen in the context of MHC class 2 and co-stimulatory signals to naïve T-cells in mesenteric lymph nodes which leads to activation, proliferation, and recognition of the cognate antigen.

Note: Gut CDI03+ DCs are unique as they also convert retinoic acid which imprints selective gut trafficking molecules such as CCR9 and $\alpha 4 \beta 7$.

Abbreviations: CD, Crohn's disease; DC, dendritic cell; MHC, major histocompatibility complex; TCR, T cell receptor. 


\section{Effector T- or B-cell}

$\alpha 4 \beta 7$ Vedolizumab; Takeda
$\alpha 4 \beta 7$ AMG181; Amgen
$\alpha 4$ Natalizumab; Elan
$\beta 7$ Etrolizumab; Genentech

PF-00547659; Pfizer

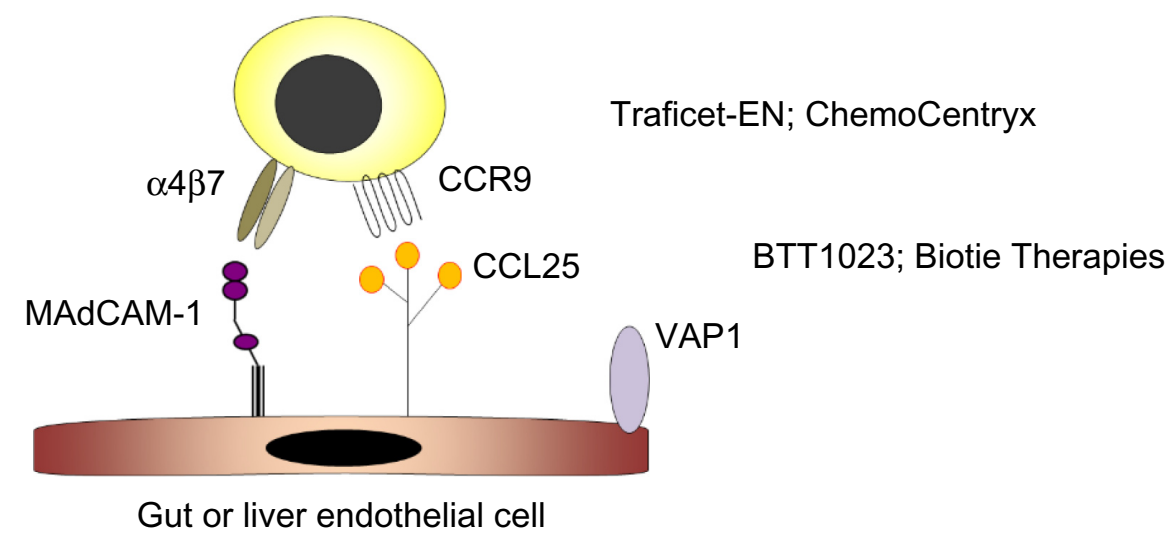

Figure 2 Drug development targeting different elements of gut-specific trafficking of immune cells in IBD.

Note: Vedolizumab and AMGI8I targets $\alpha 4 \beta 7$, natalizumab targets $\alpha 4$, etrolizumab selectively targets $\beta 7$, PF-00547659 targets MAdCAMI, GSK-1605786 (CCX-282; Traficet-EN) targets CCR9, and BTTI023 targets VAPI. Manufacturing details: Takeda: Osaka, Japan; Amgen: Thousand Oaks, CA, USA; Elan: Dublin, Ireland; Genentech: South San Francisco, CA, USA; Pfizer: New York, NY, USA; ChemoCentryx: Mountain View, CA, USA; Biotie Therapies: Turku, Finland.

Abbreviation: IBD, inflammatory bowel disease.

$P<0.01)$. This study demonstrated the potential therapeutic impact of interfering with the recruitment ("trafficking") of circulating inflammatory cells to areas of intestinal inflammation in response to signaling mechanisms. ${ }^{55}$

\section{Natalizumab-first adhesion molecule antagonist in IBD}

The first biological therapy to specifically target gut-specific leukocyte trafficking and recruitment in IBD was natalizumab (Tysabri $^{\circledR}$; Biogen Canada, Mississauga, ON, Canada). ${ }^{56}$ Acting as an antagonist against the cell adhesion molecule $\alpha 4$-integrin, this humanized $\mathrm{mAb}$ has the ability to block both $\alpha 4 \beta 1$ and $\alpha 4 \beta 7$ integrins (which bind to VCAM- 1 and MAdCAM-1, respectively), making it selective for inflammation and infection, but nonselective for the GI tract. As VCAM-1 also has a role in cell survival, its mode of action may also impact integrin-dependent survival of cells, thereby promoting cell apoptosis of leukocytes already recruited to affected tissue.$^{57}$ In a double-blind placebo-controlled study of 248 patients with moderate-to-severe $\mathrm{CD}$, this drug proved to be efficacious and demonstrated significantly higher clinical response rates at weeks $4,6,8$, and 12 in patients that received two infusions of either natalizumab $3 \mathrm{mg} / \mathrm{kg}$ or natalizumab $6 \mathrm{mg} / \mathrm{kg}$, compared with those who received placebo. ${ }^{58}$ The onset of treatment was rapid and sustained through 8 weeks. Clinical efficacy of this drug was demonstrated in a number of subsequent clinical trials for $\mathrm{CD}$, as summarized in Table 3 .

Because natalizumab not only targets gut-specific inflammation through $\alpha 4 \beta 7 /$ MAdCAM- 1 interactions, but also impacts nonspecific inflammation through $\alpha 4 \beta 1$ /VCAM- 1 binding, the drug gained an indication for the treatment of multiple sclerosis as $\alpha 4 \beta 1 / \mathrm{VCAM}-1$ represents an important inflammatory pathway in the central nervous system. ${ }^{59}$ Unfortunately, the ability of this drug to interfere with the $\alpha 4 \beta 1 /$ VCAM-1-mediated inflammatory pathway also became its downfall, as it was capable of suppressing the body's natural immunologic control of the John Cummingham virus in individuals who were infected. Reactivation of the John Cummingham virus can lead to the development of PML, a rare and fatal demyelinating disease of the brain, as was observed in a small number of individuals treated with natalizumab. ${ }^{60,61}$ Given the significant risk for PML and the poor risk-benefit ratio of this drug, natalizumab is no longer used for the treatment of CD.

\section{Vedolizumab-gut-specific targeting of leukocyte trafficking in IBD}

Efforts have been refined toward specifically targeting the gut-specific $\alpha 4 \beta 7$ integrin in order to minimize, and ideally prevent, unwanted systemic immunosuppression associated with $\alpha 4 \beta 1 / V C A M-1$ interactions (Figure 2). Potential emerging therapies in development include selective targeting of the $\beta 7$ subunit (etrolizumab; Genentech) and selective inhibition of the MAdCAM-1 (PF-00547659; Pfizer). ${ }^{47}$ VDZ (Entyvio ${ }^{\circledR}$; Takeda Pharmaceutical Company Limited) is, however, the lead compound in this class and it has recently become commercially available for the treatment of IBD. Administered as an intravenous infusion, VDZ is a humanized anti- $\alpha 4 \beta 7$ integrin IgG1 mAb that binds the activated heterodimer of $\alpha 4 \beta 7 .{ }^{62}$ Whereby natalizumab only recognized the $\alpha 4$ subunit of the $\alpha 4 \beta 1$ heterodimer with no specificity for the $\beta$ subunit, VDZ solely recognizes the activated $\alpha 4 \beta 7$ heterodimeric integrin 
Table 3 Summary of pivotal natalizumab studies in Crohn's disease

\begin{tabular}{|c|c|c|c|}
\hline Study & $\begin{array}{l}\text { Anti-TNF } \alpha \text { Tx naïve } \\
\text { or experienced }\end{array}$ & Dosing regimen & Key endpoint outcome(s) \\
\hline Gordon et $\mathrm{al}^{63}$ & Not reported & $\begin{array}{l}\text { NTZ Tx Group: } 3 \mathrm{mg} / \mathrm{kg} \text { IV at wk } 0 \\
\text { PBO Group: PBO at wk } 0\end{array}$ & $\begin{array}{l}\text { Mean reduction in CDAI score } \\
\text { NTZ Tx Group: } 45 \text { points } \\
\text { PBO Group: I I points } \\
\text { Wk } 2 \text { clinical remission }(C D A I<\mid 50) \\
\text { NTZ Tx Group: } 39 \%(7 / / 8) \\
\text { PBO Group: } 8 \%(1 / / 2)\end{array}$ \\
\hline Ghosh et al $\left.\right|^{58}$ & Naïve & $\begin{array}{l}\text { NTZ/PBO Tx Group: NTZ } 3 \mathrm{mg} / \mathrm{kg} \text { IV } \\
\text { at wk } 0, \text { PBO at wk } 4 \\
\text { NTZ } 3 \mathrm{mg} / \mathrm{kg} \text { Tx Group: NTZ } 3 \mathrm{mg} / \mathrm{kg} \text { IV } \\
\text { at wks } 0 \text { and } 4 \\
\text { NTZ } 6 \mathrm{mg} / \mathrm{kg} \text { Tx Group: NTZ } 6 \mathrm{mg} / \mathrm{kg} \text { IV } \\
\text { at wks } 0 \text { and } 4 \\
\text { PBO Group: PBO at wks } 0 \text { and } 4\end{array}$ & $\begin{array}{l}\text { Wk } 6 \text { clinical remission (CDAI < I50) } \\
\text { NTZ/PBO Tx Group: 29\% (20/68) } \\
\text { NTZ } 3 \text { mg/kg Tx Group: 44\% (29/66) } \\
\text { NTZ } 6 \text { mg/kg Tx Group: } 31 \%(16 / 5 \mathrm{I}) \\
\text { PBO Group: 27\% (I7/63) } \\
\text { Wk } 6 \text { clinical response (CDAl-70 response) } \\
\text { NTZ/PBO Tx Group: 59\% (40/68) } \\
\text { NTZ } 3 \text { mg/kg Tx Group: 7I\% (47/66) } \\
\text { NTZ } 6 \text { mg/kg Tx Group: 57\% (29/5I) } \\
\text { PBO Group: } 38 \%(24 / 63)\end{array}$ \\
\hline $\begin{array}{l}\text { ENACT-I } \\
\left.\text { (Sandborn et a }{ }^{61}\right)\end{array}$ & Naïve and experienced & $\begin{array}{l}\text { NTZ Tx Group: } 300 \mathrm{mg} I V \text { at wks } 0,4 \text {, and } 8 \\
\text { PBO Group: PBO at wks 0, 4, and } 8\end{array}$ & $\begin{array}{l}\text { Wk I0 clinical response (CDAI-70 response) } \\
\text { NTZ Tx Group: 56\% }(408 / 724) \\
\text { PBO Group: } 49 \%(88 / / 8 I) \\
\text { Wk I0 clinical remission }(\text { CDAI <I50) } \\
\text { NTZ Tx Group: } 37 \%(267 / 724) \\
\text { PBO Group: } 30 \%(55 / / 8 I)\end{array}$ \\
\hline $\begin{array}{l}\text { ENACT-2 } \\
\left(\text { Sandborn et al }{ }^{61}\right)\end{array}$ & $\begin{array}{l}\text { Responded to NTZ induction } \\
\text { therapy in ENACT-I }\end{array}$ & $\begin{array}{l}\text { NTZ Tx Group: } 300 \text { mg IV q4wks } \\
\text { through wk } 56 \\
\text { PBO Group: PBO q4wks through } \\
\text { wk } 56\end{array}$ & $\begin{array}{l}\text { Sustained clinical response (CDAI-70 } \\
\text { response) wk I2 through wk } 36 \\
\text { NTZ Tx Group: } 61 \%(103 / / 68) \\
\text { PBO Group: } 28 \%(48 / / 70) \\
\text { Sustained clinical remission (CDAI < I50) } \\
\text { wk I2 through wk } 36 \\
\text { NTZ Tx Group: } 44 \%(57 / / 30) \\
\text { PBO Group: } 26 \%(3 \mathrm{I} / / 20)\end{array}$ \\
\hline $\begin{array}{l}\text { ENCORE } \\
\left(\text { Targan et } \mathrm{al}^{64}\right)\end{array}$ & Naïve and experienced & $\begin{array}{l}\text { NTZ Tx Group: } 300 \mathrm{mg} \\
\text { IV at wks } 0,4 \text {, and } 8 \\
\text { PBO Group: PBO at wks } 0,4 \text {, } \\
\text { and } 8\end{array}$ & $\begin{array}{l}\text { Sustained clinical response (CDAI-70 } \\
\text { response) wk } 8 \text { through wk I2 } \\
\text { NTZ Tx Group: } 48 \%(124 / 259) \\
\text { PBO Group: } 32 \%(8 I / 250) \\
\text { Sustained clinical remission (CDAI < I50) } \\
\text { wk } 8 \text { through wk I2 } \\
\text { NTZ Tx Group: } 26 \%(68 / 259) \\
\text { PBO Group: } 16 \%(40 / 250)\end{array}$ \\
\hline Sands et $\mathrm{a}^{65}$ & $\begin{array}{l}\text { Experienced (concurrent } \\
\mathrm{IFX} 5 \mathrm{mg} / \mathrm{kg} \text { q8wks) }\end{array}$ & $\begin{array}{l}\text { NTZ/IFX TX Group: NTZ } 300 \mathrm{mg} \\
\text { IV at wks } 0,4 \text {, and } 8+\text { concurrent } \\
\text { IFX } 5 \mathrm{mg} / \mathrm{kg} \text { IV q8wks } \\
\text { PBO/IFX Group: PBO at wks } 0,4 \text {, } \\
\text { and } 8+\text { concurrent IFX } 5 \mathrm{mg} / \mathrm{kg} \text { IV q8wks }\end{array}$ & $\begin{array}{l}\text { Clinical remission }(C D A I \leq \mid 50) \text { at any time } \\
\text { during study }\left(2^{\circ} \text { endpoint) }\right. \\
\text { NTZ/IFX Tx Group: } 46 \%(24 / 52) \\
\text { PBO/IFX Group: } 4 \text { I } \%(I I / 27)\end{array}$ \\
\hline
\end{tabular}

Notes: Clinical remission by Clinical Disease Activity Index (CDAl) score $<150$ defined as CDAl score less than 150 points. CDAl score $\leq 150$ defined as CDAl score less than or equal to 150 points. Clinical response by CDAI (CDAl-70 response) score defined as decrease from baseline in CDAl score by $\geq 70$ points.

Abbreviations: IFX, Infliximab; IV, intravenous; NTZ, natalizumab; PBO, placebo; TNF $\alpha$, tumor necrosis factor alpha; Tx, treatment; wk, week.

and not the individual $\alpha 4$ or $\beta 7$ subunits. This binding specificity results in gut-selective blockade of lymphocyte trafficking, thereby making it an attractive treatment option for IBD.

\section{Vedolizumab in UC}

The role of VDZ as an effective induction and maintenance therapy for UC was established in the GEMINI 1 study. ${ }^{66}$
This Phase III integrated induction and maintenance randomized, double-blind, placebo-controlled trial enrolled patients with active UC (defined as a Mayo score of 6-12 at screening) who had failed or were intolerant to glucocorticosteroids, immunomodulators, and/or anti-TNF $\alpha$ therapy. The induction therapy trial included a total of 895 patients in two treatment cohorts. Cohort 1 comprised 374 patients - stratified by 
corticosteroid use/nonuse, concomitant immunomodulator use/nonuse, and prior use of $\mathrm{TNF} \alpha$ antagonist - who were randomized in a 3:2 ratio to receive VDZ $300 \mathrm{mg}$ or placebo at weeks 0 and 2. A total of 521 patients in cohort 2 received open-label VDZ $300 \mathrm{mg}$ at weeks 0 and 2 . Both cohorts underwent endoscopic disease evaluation at week 6 to assess for clinical response, defined as a decrease in an individual's Mayo score of at least 3 points (and at least 30\% from baseline), as well as a decrease in the rectal bleeding subscore of at least 1 point or an absolute rectal bleeding subscore of 0 or 1 . The 121 patients from cohort 1 and 252 patients from cohort 2 who had a clinical response to VDZ at induction continued in the maintenance therapy trial for up to 52 weeks and were randomly assigned (1:1:1) to receive VDZ 300 mg q8weeks, VDZ 300 mg q4weeks, or placebo. Patients $(n=373)$ who did not show response at week 6 to VDZ induction therapy received VDZ $300 \mathrm{mg}$ q4weeks as maintenance; patients $(n=149)$ who received placebo as induction therapy continued to received placebo for the duration of the maintenance trial.

A significantly significant $47.1 \%$ of patients from cohort 1 treated with VDZ showed a clinical response at week 6 vs $25.5 \%$ for the placebo group ( $P<0.001) ; 44.3 \%$ of patients from cohort 2 treated with open-label VDZ also showed a clinical response. Clinical remission at week 52, defined as a Mayo score $\leq 2$ with no subscore greater than 1 , was achieved in $41.8 \%$ of patients treated with VDZ $300 \mathrm{mg}$ q8weeks and $44.8 \%$ of patients treated with VDZ $300 \mathrm{mg}$ q4weeks compared with $15.9 \%$ of individuals switched to placebo for maintenance $(P<0.001$ against placebo for both VDZ regimens). The efficacy between VDZ $300 \mathrm{mg}$ dosed q4weeks compared with q8weeks was not appreciably different. Commonly reported adverse events, serious infections, opportunistic infections, and enteric infections occurred in patients treated with VDZ at a frequency similar to those treated with placebo. ${ }^{66}$ Table 4 summarizes the pivotal VDZ studies conducted in UC.

\section{Vedolizumab in CD}

An identical study design framework was utilized in the GEMINI $2^{67}$ study to evaluate the effectiveness of VDZ as induction and maintenance therapy in active CD. The study population was patients with moderate-to-severe $\mathrm{CD}$, defined as a Clinical Disease Activity Index (CDAI) score between 220 and 450 points at screening, who had failed or were intolerant to glucocorticosteroids, immunomodulators, and/or anti-TNF $\alpha$ therapy. Three hundred and sixty-eight patients, stratified by corticosteroid use/nonuse, concomitant immunomodulator use/nonuse, and prior use of TNF $\alpha$ antagonist, were entered into cohort 1 and randomized to receive VDZ $300 \mathrm{mg}$ or placebo at weeks 0 and 2 (3:2 ratio). Cohort 2 consisted of 747 patients who were infused with open-label VDZ $300 \mathrm{mg}$ at weeks 0 and 2. Endoscopic evaluation was performed at week 6 to assess for clinical remission (CDAI score of $\leq 150$ points) and CDAI-100 response (decrease in CDAI score of 100 or more points from baseline). Patients $(n=461)$ who achieved at least a 70 point decrease in the CDAI score at week 6 (96 patients from cohort $1 ; 365$ patients from cohort 2$)$ were randomly assigned (1:1:1) to receive VDZ 300 mg q8weeks, VDZ 300 mg q4weeks, or placebo for up to 52 weeks within the maintenance therapy trial. Participants $(n=506)$ who did not show response at week 6 to VDZ induction therapy received VDZ $300 \mathrm{mg}$ q4weeks as maintenance and those individuals $(n=168)$ who received placebo as induction therapy continued to received placebo for the duration of the maintenance trial.

At week 6 endoscopic evaluation, $14.5 \%$ of patients from cohort 1 induced with VDZ were in clinical remission at week 6 compared with $6.8 \%$ for the placebo group $(P=0.02)$; although not found to be statistically different $(P=0.23)$, $31.4 \%$ of cohort 1 patients treated with VDZ and $25.7 \%$ of patients treated with placebo achieved a CDAI-100 response at this same time point. Clinical remission was observed in $17.7 \%$ of patients from cohort 2 treated with open-label VDZ, with $34.4 \%$ having a CDAI- 100 clinical response. For patients from both cohorts who responded to VDZ induction therapy, clinical remission at week 52 was confirmed in $39.0 \%$ of patients treated with VDZ $300 \mathrm{mg}$ q8weeks and $36.4 \%$ of patients treated with VDZ $300 \mathrm{mg}$ q4weeks compared with $21.6 \%$ of individuals switched to placebo for maintenance $(P<0.001$ for VDZ q8weeks vs placebo; $P=0.004$ for VDZ q4weeks vs placebo). The frequency of adverse events (discussed next) was higher in the VDZ treatment group compared with individuals receiving placebo. ${ }^{67}$

The GEMINI 3 study ${ }^{68}$ was carried out to assess the efficacy and safety of VDZ as an induction agent for moderately-to-severely active CD patients (CDAI score between 220 and 400 at baseline) with previous anti-TNF $\alpha$ therapy failure, defined as primary nonresponse, secondary nonresponse (loss of response), or intolerance to 1 or more TNF $\alpha$ antagonists. This Phase III, double-blind, placebocontrolled trial lasting 10 weeks enrolled 416 patients of which $315(75.7 \%)$ were individuals with previous TNF $\alpha$ antagonist failure and $101(24.3 \%)$ were anti-TNF $\alpha$ naïve. Patients were randomized in a 1:1 fashion to receive VDZ $300 \mathrm{mg}$ or placebo at weeks 0,2 , and 6 . In patients with prior TNF $\alpha$ antagonist failure, clinical remission (CDAI score $\leq 150$ points) was not statistically significant at week 
Table 4 Summary of pivotal vedolizumab studies in ulcerative colitis and Crohn's disease

\begin{tabular}{|c|c|c|c|c|}
\hline Study & IBD type & $\begin{array}{l}\text { Anti-TNF } \alpha \text { Tx naïve } \\
\text { or experienced }\end{array}$ & Dosing regimen & Key endpoint outcome(s) \\
\hline Feagan et al ${ }^{69}$ & UC & Naive & $\begin{array}{l}\alpha 4 \beta 70.15 \mathrm{mg} / \mathrm{kg} \text { SC Tx } \\
\text { Group: } 0.15 \mathrm{mg} / \mathrm{kg} \mathrm{SC} \text { single dose } \\
\alpha 4 \beta 70.15 \mathrm{mg} / \mathrm{kg} \text { IV Tx } \\
\text { Group: } 0.15 \mathrm{mg} / \mathrm{kg} \text { IV single dose } \\
\alpha 4 \beta 70.5 \mathrm{mg} / \mathrm{kg} \text { IV Tx } \\
\text { Group: } 0.5 \mathrm{mg} / \mathrm{kg} \mathrm{IV} \mathrm{single} \mathrm{dose} \\
\alpha 4 \beta 72.0 \mathrm{mg} / \mathrm{kg} \text { IV Tx } \\
\text { Group: } 2.0 \mathrm{mg} / \mathrm{kg} \text { IV single dose } \\
\text { PBO Group: PBO single dose }\end{array}$ & $\begin{array}{l}\text { Day } 30 \text { meaningful endoscopic response } \\
\alpha 4 \beta 70.15 \text { SC Tx Group: 20\% (I/5) } \\
\alpha 4 \beta 70.15 \text { IV Tx Group: 0\% (0/5) } \\
\alpha 4 \beta 70.5 \text { IV Tx Group: } 60 \%(3 / 5) \\
\alpha 4 \beta 72.0 \text { IV Tx Group: } 20 \%(I / 5) \\
\text { PBO Group: } 25 \%(2 / 8)\end{array}$ \\
\hline Feagan et $\mathrm{al}^{70}$ & UC & Not reported & $\begin{array}{l}\text { MLN02 } 0.5 \mathrm{mg} / \mathrm{kg} \text { Tx } \\
\text { Group: } 0.5 \mathrm{mg} / \mathrm{kg} \mathrm{IV} \text { on days I and } 29 \\
\text { MLN02 } 2.0 \mathrm{mg} / \mathrm{kg} \text { Tx } \\
\text { Group: } 2.0 \mathrm{mg} / \mathrm{kg} \mathrm{IV} \text { on days I and } 29 \\
\text { PBO Group: PBO on days I and } 29\end{array}$ & $\begin{array}{l}\text { Wk } 6 \text { clinical remission (UCCS and MBS) } \\
\text { MLN02 } 0.5 \mathrm{mg} / \mathrm{kg} \text { Tx Group: 33\% (19/58) } \\
\text { MLN02 } 2.0 \mathrm{mg} / \mathrm{kg} \text { Tx Group: 32\% (19/60) } \\
\text { PBO Group: I4\% (9/63) } \\
\text { Wk } 6 \text { decrease in UCCS } \geq 3 \text { points } \\
\text { MLN02 } 0.5 \mathrm{mg} / \mathrm{kg} \text { Tx Group: } 66 \% \text { (38/58) } \\
\text { MLN02 } 2.0 \mathrm{mg} / \mathrm{kg} \text { Tx Group: } 53 \%(32 / 60) \\
\text { PBO Group: 33\% (2I/63) } \\
\text { Wk } 6 \text { endoscopically evident remission } \\
\text { (MBS =0) } \\
\text { MLN02 } 0.5 \mathrm{mg} / \mathrm{kg} \text { Tx Group: } 28 \%(16 / 58) \\
\text { MLN02 } 2.0 \mathrm{mg} / \mathrm{kg} \text { Tx Group: } 12 \%(7 / 60) \\
\text { PBO Group: } 8 \%(5 / 63)\end{array}$ \\
\hline Feagan et $\mathrm{al}^{71}$ & $C D$ & Experienced & $\begin{array}{l}\text { MLN0002 } 2.0 \mathrm{mg} / \mathrm{kg} \mathrm{Tx} \\
\text { Group: } 2.0 \mathrm{mg} / \mathrm{kg} \mathrm{IV} \text { on days I and } 29 \\
\text { MLN0002 } 0.5 \mathrm{mg} / \mathrm{kg} \text { Tx } \\
\text { Group: } 0.5 \mathrm{mg} / \mathrm{kg} \mathrm{IV} \text { on days I and } 29 \\
\text { PBO Group: PBO on days I and } 29\end{array}$ & $\begin{array}{l}\text { Day } 57 \text { clinical response (CDAl-70 response) } \\
\text { MLN0002 } 2.0 \mathrm{mg} / \mathrm{kg} \text { Tx Group: 53\% (34/65) } \\
\text { MLN0002 } 0.5 \mathrm{mg} / \mathrm{kg} \text { Tx Group: 49\% (30/62) } \\
\text { PBO Group: 4l\% (24/58) } \\
\text { Day } 57 \text { clinical remission (CDAl < I50) } \\
\text { MLN0002 } 2.0 \mathrm{mg} / \mathrm{kg} \text { Tx Group: 37\% (24/65) } \\
\text { MLN0002 } 0.5 \mathrm{mg} / \mathrm{kg} \text { Tx Group: 30\% (19/62) } \\
\text { PBO Group: } 21 \% \text { (I3/58) }\end{array}$ \\
\hline Parikh et a ${ }^{72}$ & UC & Naïve and experienced & $\begin{array}{l}\text { VDZ } 2 \mathrm{mg} / \mathrm{kg} \text { Tx } \\
\text { Group: } 2 \mathrm{mg} / \mathrm{kg} \text { IV on days I, I5, } 29 \text { and } 85 \\
\text { VDZ } 6 \mathrm{mg} / \mathrm{kg} \text { Tx Group: } 6 \mathrm{mg} / \mathrm{kg} \\
\text { IV on days I, I5, } 29 \text { and } 85 \\
\text { VDZ I0 mg/kg Tx Group: } 10 \mathrm{mg} / \mathrm{kg} \\
\text { IV on days I, I5, } 29 \text { and } 85 \\
\text { PBO Group: PBO on days I, I5, } 29 \text { and } 85\end{array}$ & $\begin{array}{l}\text { Sustained clinical response (partial Mayo score) } \\
\text { day } 29 \text { through day } 253 \\
\text { Combined VDZ cohort: consistently } \\
\geq 50 \% \text { at majority of visits } \\
\text { PBO Group: } 22 \%-33 \%\end{array}$ \\
\hline $\begin{array}{l}\text { GEMINI I } \\
\text { (Feagan } \\
\text { et } \mathrm{al}^{66} \text { ) }\end{array}$ & UC & Naïve and experienced & $\begin{array}{l}\text { Induction therapy trial: } \\
\text { Cohort I (Randomized Tx) } \\
\text { VDZ Tx Group: } 300 \mathrm{mg} \text { IV at wks } 0 \text { and } 2 \\
\text { PBO Group: PBO at wks } 0 \text { and } 2 \\
\text { Cohort } 2 \text { (Open Label Tx) } \\
\text { OL VDZ Tx Group: OL VDZ } 300 \mathrm{mg} \text { at } \\
\text { wks } 0 \text { and } 2 \\
\text { Maintenance therapy trial: VDZ q8wks Tx } \\
\text { Group: } 300 \mathrm{mg} \text { IV q8wks for up to } 52 \text { wks } \\
\text { VDZ q4wks Tx Group: } 300 \mathrm{mg} \text { IV q4wks } \\
\text { for up to } 52 \text { wks } \\
\text { PBO Group: PBO for up to } 52 \text { wks }\end{array}$ & $\begin{array}{l}\text { Wk } 6 \text { clinical response (Mayo score) } \\
\text { Cohort I VDZ Tx Group: 47.1\% (I06/225) } \\
\text { Cohort } 2 \text { OL VDZ Tx Group: 44.3\% (23I/52I) } \\
\text { PBO Group: 25.5\% (38/I49) } \\
\text { Wk } 6 \text { clinical remission (Mayo score) } \\
\text { Cohort I VDZ Tx Group: I6.9\% (38/225) } \\
\text { Cohort } 2 \text { OL VDZ Tx Group: } 19.2 \% \\
\text { (I00/52I) } \\
\text { PBO Group: 5.4\% (8/I49) } \\
\text { Wk } 52 \text { clinical remission (Mayo score) } \\
\text { VDZ q8wks Tx Group: } 41.8 \%(5 \text { I/I22) } \\
\text { VDZ q4wks Tx Group: 44.8\% (5I//25) } \\
\text { PBO Group: I5.9\% (20//26) }\end{array}$ \\
\hline
\end{tabular}


Table 4 (Continued)

\begin{tabular}{|c|c|c|c|c|}
\hline Study & IBD type & $\begin{array}{l}\text { Anti-TNF } \alpha \text { Tx naïve } \\
\text { or experienced }\end{array}$ & Dosing regimen & Key endpoint outcome(s) \\
\hline $\begin{array}{l}\text { GEMINI } 2 \\
\text { (Sandborn } \\
\text { et } \mathrm{al}^{67} \text { ) }\end{array}$ & $C D$ & Naïve and experienced & $\begin{array}{l}\text { Induction therapy trial: Cohort I } \\
\text { (Randomized Tx) } \\
\text { VDZ Tx Group: } 300 \mathrm{mg} \text { IV at wks } 0 \text { and } 2 \\
\text { PBO Group: PBO at wks } 0 \text { and } 2 \\
\text { Cohort } 2 \text { (Open Label Tx) OL VDZ Tx } \\
\text { Group: OL VDZ } 300 \mathrm{mg} \text { at wks } 0 \text { and } 2 \\
\text { Maintenance therapy trial: } \\
\text { VDZ q8wks Tx Group: } 300 \mathrm{mg} \text { IV q8wks } \\
\text { for up to } 52 \text { wks } \\
\text { VDZ q4wks Tx Group: } 300 \mathrm{mg} \text { IV q4wks } \\
\text { for up to } 52 \text { wks } \\
\text { PBO Group: PBO for up to } 52 \text { wks }\end{array}$ & 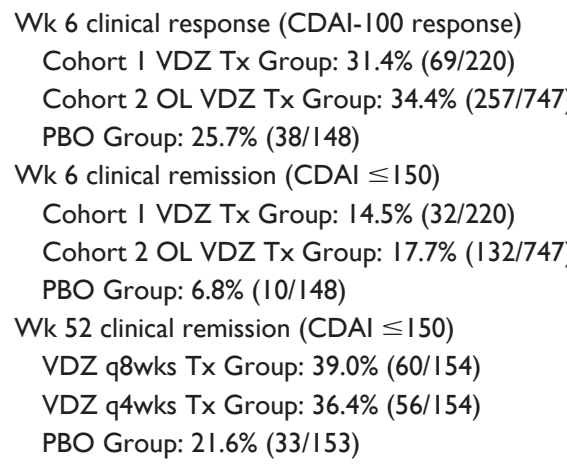 \\
\hline $\begin{array}{l}\text { GEMINI } 3 \\
\text { (Sands } \\
\left.\text { et } \mathrm{al}^{68}\right)\end{array}$ & $C D$ & Experienced & $\begin{array}{l}\text { VDZ Tx Group: VDZ } 300 \mathrm{mg} \text { IV at wks } \\
0,2 \text { and } 6 \\
\text { PBO Group: PBO at wks 0, 2, and } 6\end{array}$ & 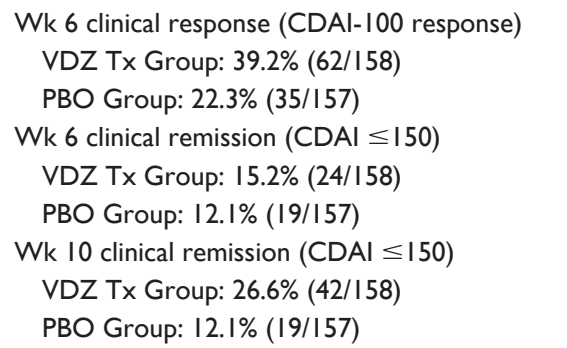 \\
\hline
\end{tabular}

Notes: Meaningful endoscopic response defined as 2 grade improvement in Modified Baron Score (MBS) from baseline. Endoscopically evident remission defined as MBS equal to 0 . Clinical remission by Ulcerative Colitis Symptom Score (UCSS) and MBS defined as UCSS of 0 or I AND MBS of 0 or I with no evidence of rectal bleeding. Clinical response by Partial Mayo Score (PMS) defined as decrease from baseline in PMS by $\geq 2$ points and $\geq 25 \%$, with absolute rectal bleeding subscore $=0$ or I OR decrease from baseline in rectal bleeding subscore $\geq I$ point. Clinical remission by Clinical Disease Activity Index (CDAI) score $<I 50$ defined as CDAl score less than I50 points. Clinical response by CDAI (CDAl-70 response) score defined as decrease from baseline in CDAl score by $\geq 70$ points. Clinical remission by Mayo score defined as Mayo score $\leq 2$ points with no individual subscore $>$ I point. Clinical response by Mayo score defined as decrease from baseline in Mayo score by $\geq 3$ points and $\geq 30 \%$, with absolute rectal bleeding subscore $=0$ or I OR decrease from baseline in rectal bleeding subscore $\geq I$ point. CDAI score $\leq I 50$ defined as CDAI score less than or equal to I50 points. Clinical response by CDAI (CDAI- 100 response) score defined as decrease from baseline in CDAl score by $\geq 100$ points.

Abbreviations: CD, Crohn's disease; IBD, inflammatory bowel disease; IV, intravenous; MBS, Modified Baron Score; OL, open label; PBO, placebo; TNF $\alpha$, tumor necrosing factor alpha; Tx, treatment; UC, ulcerative colitis; UCCS, Ulcerative Colitis Clinical Score; VDZ, vedolizumab; wk, week.

$6(15.2 \%$ of VDZ-treated patients vs $12.1 \%$ of placebotreated patients; $P=0.433)$, but was statistically significant at week 10 (26.6\% of VDZ-treated patients vs $12.1 \%$ of placebo-treated patients; nominal $P=0.001)$. As CDAI-100 response ( $\geq 100$ point decrease from baseline CDAI score) was observed in $39.2 \%$ of patients receiving VDZ at week 6 compared with $22.3 \%$ of patients treated with placebo ( $P=0.001)$, the authors of the study concluded the onset of clinical remission is likely more gradual in this patient population, thereby encouraging clinicians to consider a time point beyond week 6 to evaluate patient response before manipulating concomitant medical therapies or abandoning VDZ as a therapeutic agent. Similar to safety data reported in the GEMINI 1 study, ${ }^{66}$ the frequency of adverse events in this study was comparable between VDZ-treated individuals and those treated with placebo. Table 4 summarizes the pivotal VDZ studies conducted in CD.

In order to evaluate VDZ as a maintenance therapy in moderately-to-severely active $\mathrm{CD}$ patients with previous
anti-TNF $\alpha$ therapy failure, an open-label VDZ extension study is presently underway with results expected in 2016. This long-term study rolls over CD patients with no unacceptable adverse events and no need for CD-related surgery during their participation in the GEMINI 3 study. ${ }^{68}$

Clinical trials data confirm VDZ to be an effective agent for the induction and maintenance of clinical remission in IBD. Entyvio ${ }^{\circledR}$ (VDZ; Takeda Pharmaceutical Company Limited, Osaka, Japan) was approved for the treatment of moderately-to-severely active UC and moderately-to-severely active CD by the US Food and Drug Administration on May 20, 2014 and the European Commission on May 27, 2014. Health Canada approved its use in moderately-to-severely active UC on January 29, 2015. VDZ can be considered for patient's naïve to anti-TNF $\alpha$ agents that have failed or are intolerant to conventional therapy with glucocorticosteroids and/or immunomodulators, or that have failed TNF $\alpha$ antagonists. Previous exposure to a TNF $\alpha$ antagonist did not substantially affect the efficacy of VDZ for inducing and 
maintaining clinical response and remission in patients with UC, ${ }^{66}$ and statistically significant clinical response and remission was achievable in patients with $C D$ who had previously failed or been intolerant to up to three anti-TNF $\alpha$ agents. ${ }^{68}$ This is an important clinical consideration when there is a significant proportion of individuals who are refractory or who ultimately lose response to anti-TNF $\alpha$ therapy. ${ }^{68}$

The Toronto Consensus Statement released in May 2015 positions VDZ as a therapy to consider in the moderatelyto-severely active ambulatory UC patient when symptoms persist after 2 weeks of oral corticosteroid therapy or if symptomatic response has not been achieved with anti-TNF $\alpha$ as monotherapy or in combination with an immunomodulator. ${ }^{12}$ It is anticipated that a formal consensus statement for the use of VDZ in CD will be forthcoming as clinicians integrate this drug into clinical care.

\section{Vedolizumab versus anti-TNF $\alpha$ therapy in Crohn's disease}

As there are no direct comparative trials, it is not clear if antiTNF $\alpha$ therapy as monotherapy or in combination with an immunosuppressant is equivalent or superior to VDZ for both the induction of remission and the maintenance of remission in CD. A recent network meta-analysis ${ }^{73}$ found VDZ to be superior only to placebo (odds ratio [OR], 2.0; 95\% Credible Interval [CrI], 1.2-3.3), azathioprine/6-mercaptopurine (OR, 1.6; 95\% CrI, 0.78-3.2), methotrexate (OR, 1.3; 95\% CrI, 0.53-3.2), and certolizumab (OR, 1.4; 95\% CrI, 0.77-2.7) for the induction of remission. When considering the maintenance of remission, VDZ was found to be superior only to placebo (OR, 2.2; 95\% CrI, 1.3-3.7), azathioprine/6-mercaptopurine (OR, 1.3; 95\% CrI, 0.65-2.3), and certolizumab (OR, 1.1; 95\% CrI, 0.57-2.1). These data are fraught with potential biases, as the individual drugs might not necessarily be targeting the same responder who may have different biology and disease distribution. As such, proper head-to-head studies are required.

\section{Vedolizumab and acute, severe IBD}

Given the observed differences in the efficacy of VDZ in UC compared with $\mathrm{CD}$, one must consider this gradual onset of clinical response and remission as a characteristic of lymphocyte trafficking modulators, as this delayed onset was also observed with natalizumab. ${ }^{61}$ We speculate there may be a necessity for a "co-inducer" such as bridging CSs when VDZ treatment is initiated, as exploratory subgroup analysis reported statistically significant increased rates of clinical remission (CDAI score $\leq 150$ points) at week 10 both in the TNF $\alpha$ antagonist failure population on concomitant CSs receiving VDZ compared with the TNF $\alpha$ antagonist failure population on concomitant CS receiving placebo $(30.2 \%$ versus $10.6 \% ; P=0.002$ ), and in the overall population on concomitant CSs receiving VDZ compared with the overall population on concomitant CS receiving placebo $(34.5 \%$ versus $12.0 \% ; P=0.0001) .{ }^{68}$ Given this gradual onset of therapeutic benefit observed in clinical trials, it is unlikely that VDZ will have a significant role in the urgent management of extremely severe or fulminant IBD.

\section{Vedolizumab safety}

With respect to the safety of VDZ, no cases of PML occurred across the three Phase III studies. ${ }^{66-68}$ In GEMINI 1, the frequency of commonly reported adverse events, serious infections, opportunistic infections, and enteric infections in UC patients treated with VDZ was similar to placebo. In comparison, the incidence of infections, serious infections, serious adverse events, and nasopharyngitis was more frequently observed in CD patients treated with VDZ compared with placebo. Nasopharyngitis, headache, arthralgia, upper respiratory tract infection, cough, abdominal pain, fatigue, and influenza are listed as the most common side effects of the drug in the Patient Medication Information leaflet (part III of product monograph) ${ }^{74}$

Clinically significant infusion reactions were uncommon, only requiring discontinuation of VDZ therapy for three individuals in GEMINI 1 and one individual in GEMINI 2 (no data reporting infusion reactions available for GEMINI 3). Immunogenicity is uncommon, with only $3.7 \%$ of the 620 patients with blood samples suitable for drug antibody testing in GEMINI 1 having VDZ antibodies at any given time through the induction and maintenance periods, and $4.1 \%$ of patients in GEMINI 2 having detectable VDZ antibodies. Pre-medications (antihistamine, hydrocortisone, corticosteroid, and/or acetaminophen) are not standardly required or recommended, unless the patient has experienced a mild-to-moderate infusion-related reaction to VDZ. Concomitant treatment with an immunomodulator was associated with a decrease in immunogenicity and may be considered for individual patients.

\section{Vedolizumab and enteric pathogens}

Clostridium difficile and other enteric infections did not occur more frequently than placebo in clinical trials, ${ }^{66-68}$ a valid concern when considering the gut-specific mechanism of action of VDZ. Wyant et $\mathrm{al}^{75}$ conducted a Phase I, randomized, double-blind, placebo-controlled, parallel-group single center non-inferiority trial, whereby 127 healthy volunteers were randomized 1:1 to receive a single dose of VDZ $750 \mathrm{mg}$ or placebo at day 0 , followed by an accelerated immunization 
dosing schedule of intramuscular hepatitis B vaccine (HBV) on days 4/32/60 and oral cholera vaccine (OCV; Dukoral $\left.{ }^{\circledR}\right)$ on days 4/18. HBV seroconversion (defined as hepatitis B surface antibody titer $\geq 10 \mathrm{IU} / \mathrm{L}$ ) and OCV seroconversion (defined as $>$ fourfold increase in serum cholera toxin antibodies from baseline) was tested at day 74. HBV seroconversion to the parenteral hepatitis B vaccine was observed in $90.3 \%$ of individuals initially treated with placebo and $88.5 \%$ of individuals treated with VDZ, whereas OCV seroconversion to the enteral OCV was observed in $96.8 \%$ of individuals initially treated with placebo and $82.5 \%$ of individuals treated with VDZ. Further, the humoral response to OCV was markedly reduced in individuals treated with VDZ who demonstrated an OCV seroconversion, compared with individuals treated with placebo who seroconverted in response to OCV, providing further evidence of the gut selectivity of this molecule. The study authors speculated that T-cell-dependent immune defenses are attenuated, but not completely blocked, in response to OCV with concurrent administration of VDZ. From this study and the safety outcomes reported in clinical trials, it may be concluded that VDZ does exert an effect on the lymphocyte trafficking to the gut, but does not obliterate an individual's own immune response to enteric infections. This is an important observation as IBD patients are more prone to infections of the gut and require appropriate immune responses to control enteric microorganisms encountered in the luminal environment while limiting the inappropriate immune response characteristic of IBD.

\section{Potential extended indications for vedolizumab}

There is the potential for extended therapeutic use of VDZ beyond IBD. Primary sclerosing cholangitis (PSC) is a chronic immune-mediated cholestatic liver disease of unknown etiology that results in progressive fibrostenotic strictures of the entire biliary tree eventually leading to liver cirrhosis and end-stage liver disease. ${ }^{76}$ PSC stands out among other forms of liver disease owing to its close association with IBD. Between $2.5 \%$ and $7.5 \%$ of individuals with IBD will eventually develop PSC and, conversely, between $60 \%$ and $70 \%$ of patients with PSC will develop IBD. ${ }^{77}$ This association is discontinuous as PSC can arise many years after the initial diagnosis of IBD or, in some instances, after a curative colectomy for UC has been performed. It is also well recognized that IBD can arise de novo after a successful liver transplant for PSC, thus suggesting a very close relationship and shared pathogenesis between PSC and IBD.

In PSC, there is aberrant expression of gut-specific chemokine CCL25 on hepatic sinusoidal endothelium which binds to CCR9 on gut tropic T-cells, activating $\alpha 4 \beta 7$ to recruit pro-inflammatory gut T-cells from the intestinal tract to the PSC liver. MAdCAM-1 and CCL25 expression, usually confined to the gut, has also been observed on liver endothelium in association with PSC, leading to increased trafficking of mucosal T-cells and chronic IBD related-liver inflammation. ${ }^{78-80}$ Therefore, VDZ may be a potential effective therapy for the treatment of PSC. To further investigate this hypothesized mechanism of chronic liver inflammation and injury, a Phase III randomized control study of VDZ in PSC is planned to commence in 2016.

Individuals with IBD often develop seronegative arthritis as an extra-intestinal manifestation of their IBD. Joint arthropathies may be the consequence of flawed mucosal leukocyte trafficking to the synovium of affected joints, as has been demonstrated in experimental models where gut derived T-cells were observed to bind to synovial tissue. ${ }^{81}$ The exact mechanism by which gut-homing lymphocytes bind to inflamed synovium is not well understood; earlier attempts hypothesized that $\alpha 4 \beta 7$ lymphocytes found in inflamed synovium must partially use integrins and adhesion molecules other than MAdCAM-1 such as VAP-1 to transmigrate across the endothelium into synovial tissue, as MAdCAM-1 is lacking on the endothelium of inflamed synovial blood vessels. ${ }^{82}$ This necessitates further investigations, but aberrant expression of gut-adhesion molecules may be implicated in seronegative arthritis given the association of this extra-intestinal manifestation with IBD. Long-term clinical use of VDZ in the IBD population combined with controlled clinical trials specifically designed to investigate the impact of this drug on seronegative arthritis will be required to further delineate the exact molecular mechanism of joint inflammation and chronic injury.

\section{Conclusion}

In summary, VDZ has emerged as a viable and efficacious alternative to TNF $\alpha$ antagonist treatment in both UC and CD without the serious complication of PML associated with its predecessor, natalizumab. The mechanism of action appears to be restricted to the gut without complete abrogation of the host immune system, preserving mucosal immunity that is relatively intact and capable of coping with enteric infections.

The future of anti-adhesion therapy in IBD will be focused on delineating the integrated, and often redundant, inflammatory pathways that contribute to chronic inflammation of the gut and associated extra-intestinal manifestations. Etrolizumab, PF-00547659 and CCR9 antagonists such as GSK-1605786 (formerly CCX-282; Traficet-EN, ChemoCentryx; New York, NY, USA) have been or continue to be 
investigated, but have not yet received regulatory approval for clinical use. The next logical progression in drug development is to consider new targets, such as the $\alpha E$ subunit of the gut-specific $\alpha E \beta 7$ integrin, or multi-target therapy such as the collaboration between ChemoCentryx and GSK (Brenford, Middlesex, UK) to develop a next-generation CCR9 inhibitor (CCX507) that works in combination with an $\alpha 4 \beta 7$ integrin antagonist to provide an amplified treatment effect that surpasses monotherapy with either agent.

Future drug development in IBD is not solely restricted to gut-specific targets, but also include intracellular messengers such as tyrosine kinases. JAK1 plays important role in signal transduction of the interleukins. Tofacitinib is a JAK inhibitor that can block this signaling pathway and is under investigation in IBD. ${ }^{83}$ Other approaches include anti-interleukin 12/23 antibody treatments ${ }^{84}$ and non-gut-selective chemokine antagonists such as anti-CXCL10 antibodies. ${ }^{85}$ It is likely that combinations of these therapies will emerge and companion diagnostics to personalize treatments to target in individuals with IBD.

\section{Acknowledgment}

This research was supported by the Canadian Institutes for Health Research (CIHR).

\section{Author contributions}

All authors contributed toward data analysis, drafting and revising the paper and agree to be accountable for all aspects of the work.

\section{Disclosure}

The authors report no conflicts of interest in this work.

\section{References}

1. The impact of inflammatory bowel disease in Canada: 2012 final report and recommendations. 2012. Available from: http://www.isupportibd. ca/pdf/ccfc-ibd-impact-report-2012.pdf.). Accessed July 4, 2015.

2. Fast facts: the impact of IBD in Canada 2012. 2012. Available from: http://isupportibd.ca/pdf/ccfc.ca-impact-report-fast-facts.pdf. Accessed July 4, 2015.

3. Molodecky NA, Soon IS, Rabi DM, et al. Increasing incidence and prevalence of the inflammatory bowel diseases with time, based on systematic review. Gastroenterology. 2012;142:46-54. e42; quiz e30.

4. Talley NJ, Abreu MT, Achkar JP, et al. An evidence-based systematic review on medical therapies for inflammatory bowel disease. American College of Gastroenterology IBD Task Force. Am J Gastroenterol. 2011; 106:S2-S25.

5. Loftus EV Jr, Shivashankar R, Tremaine W, Harmsen WS, Zinsmeister AR. Updated incidence and prevalence of Crohn's disease and ulcerative colitis in Olmsted County, Minnesota (1970-2011). ACG 2014 Annual Scientific Meeting; October 2014.

6. Rocchi A, Benchimol EI, Bernstein CN, et al. Inflammatory bowel disease: a Canadian burden of illness review. Can J Gastroenterol. 2012;26:811-817.
7. Bernklev T, Jahnsen J, Schulz T, et al. Course of disease, drug treatment and health-related quality of life in patients with inflammatory bowel disease 5 years after initial diagnosis. Eur J Gastroenterol Hepatol. 2005; 17:1037-1045.

8. Theede K, Kiszka-Kanowitz M, Nordgaard-Lassen I, Mertz Nielsen A. The impact of endoscopic inflammation and mucosal healing on healthrelated quality of life in ulcerative colitis patients. J Crohn's Colitis. 2015;9:625-632.

9. Wright EK, Kamm MA. Impact of drug therapy and surgery on quality of life in Crohn's disease: a systematic review. Inflamm Bowel Dis. 2015;21:1187-1194.

10. McLean LP, Shea-Donohue T, Cross RK. Vedolizumab for the treatment of ulcerative colitis and Crohn's disease. Immunotherapy. 2012;4:883-898.

11. Cheng FK, McLean LP, Cross RK. What is the role of vedolizumab in the era of anti-TNF agents? Ann Transl Med. 2014;2:4.

12. Bressler B, Marshall JK, Bernstein CN, et al. Clinical practice guidelines for the medical management of nonhospitalized ulcerative colitis: the Toronto consensus. Gastroenterology. 2015;148:1035-1058. e3.

13. Nguyen GC, Devlin SM, Afif W, et al. Defining quality indicators for best-practice management of inflammatory bowel disease in Canada. Can J Gastroenterol Hepatol. 2014;28:275-285.

14. Kaplan GG, Seow CH, Ghosh S, et al. Decreasing colectomy rates for ulcerative colitis: a population-based time trend study. Am J Gastroenterol. 2012;107:1879-1887.

15. Bernstein CN, Loftus EV Jr, Ng SC, et al. Hospitalisations and surgery in Crohn's disease. Gut. 2012;61:622-629.

16. Singh S, Al-Darmaki A, Frolkis AD, et al. Post operative mortality among patients with inflammatory bowel diseases: a systematic review and meta-analysis of population-based studies. Gastroenterology. 2015;149:928-937.

17. van Dullemen HM, van Deventer SJ, Hommes DW, et al. Treatment of Crohn's disease with anti-tumor necrosis factor chimeric monoclonal antibody (cA2). Gastroenterology. 1995;109:129-135.

18. Janssen. Remicade ${ }^{\circledR}$ (infliximab) Product monograph. 2014. Available from: http://www.janssen.ca/subcategory_docdownload?id=2263. Accessed July 15, 2015.

19. Abbvie. Humira ${ }^{\circledR}$ (adalimumab) Product monograph. 2015. Available from: http://www.abbvie.ca/content/dam/abbviecorp/ca/english/docs/ HUMIRA_PM_EN.pdf. Accessed July 15, 2015.

20. Janssen. Simponi ${ }^{\circledR}$ (golimumab) Product monograph. 2014. Available from: http://www.janssen.ca/subcategory_docdownload?id=2278. Accessed July 15, 2015.

21. UCB Canada. Cimzia ${ }^{\circledR}$ (certolizumab pegol) Product monograph. 2014. Available from: http://www.ucb-canada.ca/_up/ucbpharma_ca_en/ documents/cimzia_pm_en_15jan2014.pdf. Accessed July 15, 2015.

22. Hanauer SB, Feagan BG, Lichtenstein GR, et al. Maintenance infliximab for Crohn's disease: the ACCENT I randomised trial. Lancet. 2002;359:1541-1549.

23. Colombel JF, Sandborn WJ, Reinisch W, et al. Infliximab, azathioprine, or combination therapy for Crohn's disease. N Engl J Med. 2010;362:1383-1395.

24. Hanauer SB, Sandborn WJ, Rutgeerts P, et al. Human anti-tumor necrosis factor monoclonal antibody (adalimumab) in Crohn's disease: the CLASSIC-I trial. Gastroenterology. 2006;130:323-333; quiz 591.

25. Sandborn WJ, Hanauer SB, Rutgeerts P, et al. Adalimumab for maintenance treatment of Crohn's disease: results of the CLASSIC II trial. Gut. 2007;56:1232-1239.

26. Colombel JF, Sandborn WJ, Rutgeerts P, et al. Adalimumab for maintenance of clinical response and remission in patients with Crohn's disease: the CHARM trial. Gastroenterology. 2007;132:52-65.

27. Hyams J, Crandall W, Kugathasan S, et al. Induction and maintenance infliximab therapy for the treatment of moderate-to-severe Crohn's disease in children. Gastroenterology. 2007;132:863-873; quiz 1165-1166.

28. Hyams JS, Griffiths A, Markowitz J, et al. Safety and efficacy of adalimumab for moderate to severe Crohn's disease in children. Gastroenterology. 2012;143:365-374. e2. 
29. Sands BE, Anderson FH, Bernstein CN, et al. Infliximab maintenance therapy for fistulizing Crohn's disease. $N$ Engl J Med. 2004;350: 876-885.

30. Targan SR, Hanauer SB, van Deventer SJH, et al. A short-term study of chimeric monoclonal antibody cA2 to tumor necrosing factor $\alpha$ for Crohn's disease. N Engl J Med. 1997;337(15):1029-1035.

31. Sandborn WJ, Rutgeerts P, Enns R, et al. Adalimumab induction therapy for Crohn disease previously treated with infliximab. Ann Intern Med. 2007;146(12):829-838.

32. Schreiber S, Rutgeerts P, Fedorak RN, et al. A randomized, placebocontrolled trial of certolizumab pegol (CDP870) for treatment of Crohn's disease. Gastroenterology. 2005;129(3):807-818.

33. Sandborn WJ, Schreiber S, Feagan BG, et al. Certolizumab pegol for active Crohn's disease: A placebo-controlled randomized trial. Clin Gastroenterol Hepatol. 2011;9(8):670-678.

34. Schreiber S, Khaliq-Kareemi M, Lawrance IC, et al. Maintenance therapy with certolizumab for Crohn's disease. NEngl J Med. 2007;357: 239-250.

35. Sandborn WJ, Schreiber S, Feagan BG, et al. Certolizumab pegol for active Crohn's disease: a placebo-controlled, randomized trial. Clin Gastroenterol Hepatol. 2011;9:670-678.

36. Rutgeerts P, Sandborn WJ, Feagan BG, et al. Infliximab for induction and maintenance therapy for ulcerative colitis. $N$ Engl J Med. 2005;353 2462-2476.

37. Reinisch W, Sandborn WJ, Hommes DW, et al. Adalimumab for induction of clinical remission in moderately to severely active ulcerative colitis: results of a randomised controlled trial. Gut. 2011;60: 780-787.

38. Sandborn WJ, van Assche G, Reinisch W, et al. Adalimumab induces and maintains clinical remission in patients with moderate-to-severe ulcerative colitis. Gastroenterology. 2012;142:257-2565. e1-e3.

39. Sandborn WJ, Feagan BG, Marano C, et al. Subcutaneous golimumab induces clinical response and remission in patients with moderateto-severe ulcerative colitis. Gastroenterology. 2014;146:85-95; quiz e14-e5.

40. Sandborn WJ, Feagan BG, Marano C, et al. Subcutaneous golimumab maintains clinical response in patients with moderate-to-severe ulcerative colitis. Gastroenterology. 2014;146:96-109. e1.

41. Hyams J, Damaraju L, Blank M, et al. Induction and maintenance therapy with infliximab for children with moderate to severe ulcerative colitis. Clin Gastroenterol Hepatol. 2012;10:391-399. e1.

42. Probert CSJ, Hearing SD, Schreiber S, et al. Infliximab in moderately severe glucocorticoid resistant ulcerative colitis: a randomised controlled trial. Gut. 2003;52:998-1002.

43. Khanna R, Sattin BD, Afif W, et al. Review article: a clinician's guide for therapeutic drug monitoring of infliximab in inflammatory bowel disease. Aliment Pharmacol Ther. 2013;38:447-459.

44. Khanna R, Feagan BG. Current and future status of therapeutic drug monitoring in the treatment of IBD. Curr Treat Options Gastroenterol. 2014;12:76-89.

45. Sandborn WJ, Gasink C, Gao LL, et al. Ustekinumab induction and maintenance therapy in refractory Crohn's disease. $N$ Engl $J$ Med. 2012;367:1519-1528

46. Sandborn WJ, Feagan BG, Fedorak RN, et al. A randomized trial of Ustekinumab, a human interleukin-12/23 monoclonal antibody, in patients with moderate-to-severe Crohn's disease. Gastroenterology. 2008;135:1130-1141.

47. Lobaton T, Vermeire S, Van Assche G, Rutgeerts P. Review article: antiadhesion therapies for inflammatory bowel disease. Aliment Pharmacol Ther. 2014;39:579-594.

48. Jaensson E, Uronen-Hansson H, Pabst O, et al. Small intestinal CD103+ dendritic cells display unique functional properties that are conserved between mice and humans. $J$ Exp Med. 2008;205:2139-2149.

49. Agace W. Generation of gut-homing T cells and their localization to the small intestinal mucosa. Immunol Lett. 2010;128:21-23.

50. Agace WW. Tissue-tropic effector T cells: generation and targeting opportunities. Nat Rev Immunol. 2006;6:682-692.
51. Iwata M, Hirakiyama A, Eshima Y, Kagechika H, Kato C, Song SY. Retinoic acid imprints gut-homing specificity on T cells. Immunity. 2004;21:527-538.

52. Mora JR, Iwata M, Eksteen B, et al. Generation of gut-homing IgAsecreting B cells by intestinal dendritic cells. Science. 2006;314 $1157-1160$.

53. Agace WW. T-cell recruitment to the intestinal mucosa. Trends Immunol. 2008;29(11):541-522.

54. Butcher EC. Leukocyte-endothelial cell recognition: three (or more) steps to specificity and diversity. Cell. 1991;67:1033-1036.

55. Podolsky DK, Lobb R, King N, et al. Attenuation of colitis in the cotton-top tamarin by anti-alpha 4 integrin monoclonal antibody. J Clin Invest. 1993;92:372-380.

56. Biogen Canada. Tysabri ${ }^{\circledR}$ (natalizumab) Product Monograph 2015. Available from: http://www.biogen.ca/Admin/Public/DWSDownload. aspx ?File $=$ Files $\% 2 \mathrm{fFiler} \% 2 \mathrm{fCanada} \% 2 \mathrm{fProduct}$ Information $\%$ 2fTYSABRI\%2f2015_04_07-TYSABRI-PM-E.pdf. Accessed July 15, 2015.

57. Postigo AA, Teixido J, Sanchez-Madrid F. The alpha 4 beta 1/ VCAM-1 adhesion pathway in physiology and disease. Res Immunol. 1993;144:723-735; discussion 54-62.

58. Ghosh S, Goldin E, Gordon FH, et al. Natalizumab for active Crohn's disease. N Engl J Med. 2003;348:24-32.

59. Yednock TA, Cannon C, Fritz LC, Sanchez-Madrid F, Steinman L, Karin N. Prevention of experimental autoimmune encephalomyelitis by antibodies against alpha4beta1 integrin. Nature. 1992;356:63-66.

60. Monaco MC, Major EO. The link between VLA-4 and JC virus reactivation. Expert Rev Clin Immunol. 2012;8:63-72.

61. Sandborn WJ, Colombel JF, Enns R, et al. Natalizumab induction and maintenance therapy for Crohn's disease. $N$ Engl J Med. 2005;353: 1912-1925.

62. Soler D, Chapman T, Yang LL, Wyant T, Egan R, Fedyk ER. The binding specificity and selective antagonism of vedolizumab, an anti\{alpha\} 4 \{beta\} 7 integrin therapeutic antibody in development for inflammatory bowel diseases. J Pharmacol Exp Ther. 2009;330(3):864-875.

63. Gordon FH, Lai CWY, Hamilton MI, et al. A randomized placebocontrolled trial of a humanized monoclonal antibody to $\alpha 4$ integrin in active Crohn's disease. Gastroenterology. 2001;121(2):268-274.

64. Targan SR, Feagan BG, Fedorak RN, et at. Natalizumab for the treatment of active Crohn's disease: results of the ENCORE trial. Gastroenterology. 2007;132(5):1672-1683.

65. Sands BE, Korazek R, Spainhour J, et al. Safety and tolerability of concurrent natalizumab treatment for patients with Crohn's disease not in remission while receiving infliximab. Inflamm Bowel Dis. 2007;13(1): $2-11$.

66. Feagan BG, Rutgeerts P, Sands BE, et al. Vedolizumab as induction and maintenance therapy for ulcerative colitis. $N$ Engl $J$ Med. 2013;369:699-710.

67. Sandborn WJ, Feagan BG, Rutgeerts P, et al. Vedolizumab as induction and maintenance therapy for Crohn's disease. N Engl J Med. 2013;369: 711-721.

68. Sands BE, Feagan BG, Rutgeerts P, et al. Effects of vedolizumab induction therapy for patients with Crohn's disease in whom tumor necrosis factor antagonist treatment failed. Gastroenterology. 2014;147: 618-627. e3.

69. Feagan BG, McDonald J, Greenberg G, et al. An ascending dose trial of a humanized alpha4 beta7 antibody in ulcerative colitis (UC) Gastroenterology. 2000;118(4):AB74.

70. Feagan BG, Greenberg G, Wild G, et al. 2005. Treatment of ulcerative colitis with a humanized antibody to the $\alpha 4 \beta 7$ integrin. $N$ Engl J Med. 2005;352(24):2499-2507.

71. Feagan BG, Greenberg GR, Wild G, et al. Treatment of active Crohn's disease with MLN0002, a humanized antibody to the $\alpha 4 \beta 7$ integrin. Clin Gastroenterol Hepatol. 2008;6(12):1370-1377.

72. Parikh A, Leach T, Wyant T, et al. Vedolizumab for the treatment of active ulcerative colitis: a randomized controlled phase 2 dose-ranging study. Inflamm Bowel Dis. 2012;18(8):1470-1479. 
73. Hazlewood GS, Rezaie A, Borman M, et al. Comparative effectiveness of immunosuppressants and biologics for inducing and maintaining remission in Crohn's disease: a network meta-analysis. Gastroenterology. 2015;148:344-354. e5; quiz e14-e5.

74. Takeda. Entyvio ${ }^{\circledR}$ (vedolizumab) Product monograph. 2015. Available from: http://www.takedacanada.com/entyviopm/ /media/countries/ca/ files/product $\% 20$ pdfs/entyviopm_eng_2015jan25.pdf. Accessed July $15,2015$.

75. Wyant T, Leach T, Sankoh S, et al. Vedolizumab affects antibody responses to immunisation selectively in the gastrointestinal tract: randomised controlled trial results. Gut. 2015;64:77-83.

76. Hirschfield GM, Karlsen TH, Lindor KD, Adams DH. Primary sclerosing cholangitis. Lancet. 2013;382:1587-1599.

77. Eksteen B. Advances and controversies in the pathogenesis and management of primary sclerosing cholangitis. Br Med Bull. 2014;110:89-98.

78. Eksteen B, Miles AE, Grant AJ, Adams DH. Lymphocyte homing in the pathogenesis of extra-intestinal manifestations of inflammatory bowel disease. Clin Med. 2004;4:173-180.

79. Eksteen B, Grant AJ, Miles A, et al. Hepatic endothelial CCL25 mediates the recruitment of CCR9+ gut-homing lymphocytes to the liver in primary sclerosing cholangitis. J Exp Med. 2004;200:1511-1517.
80. Adams DH, Eksteen B. Aberrant homing of mucosal T cells and extra-intestinal manifestations of inflammatory bowel disease. Nat Rev Immunol. 2006;6:244-251.

81. Salmi M, Andrew DP, Butcher EC, Jalkanen S. Dual binding capacity of mucosal immunoblasts to mucosal and synovial endothelium in humans: dissection of the molecular mechanisms. J Exp Med. 1995; 181:137-149.

82. Salmi M, Jalkanen S. Endothelial ligands and homing of mucosal leukocytes in extraintestinal manifestations of IBD. Inflamm Bowel Dis. 1998;4:149-156.

83. Sandborn WJ, Ghosh S, Panes J, et al. Tofacitinib, an oral Janus kinase inhibitor, in active ulcerative colitis. $N$ Engl J Med. 2012;367: 616-624.

84. Bravata I, Fiorino G, Allocca M, Repici A, Danese S. New targeted therapies such as anti-adhesion molecules, anti-IL-12/23 and anti-Janus kinases are looking toward a more effective treatment of inflammatory bowel disease. Scand J Gastroenterol. 2015;50:113-120.

85. Rivera-Nieves J. Strategies that target leukocyte traffic in inflammatory bowel diseases: recent developments. Curr Opin Gastroenterol. $2015 ; 31: 441-448$.
Biologics: Targets \& Therapy

\section{Publish your work in this journal}

Biologics: Targets \& Therapy is an international, peer-reviewed journal focusing on the patho-physiological rationale for and clinical application of Biologic agents in the management of autoimmune diseases, cancers or other pathologies where a molecular target can be identified. This journal is indexed on PubMed Central, CAS, EMBase, Scopus

\section{Dovepress}

and the Elsevier Bibliographic databases. The manuscript management system is completely online and includes a very quick and fair peerreview system, which is all easy to use. Visit http://www.dovepress. com/testimonials.php to read real quotes from published authors. 